\title{
How effective are hiring subsidies to reduce long-term unemployment among prime-aged jobseekers? Evidence from Belgium
}

Citation for published version (APA):

Desiere, S., \& Cockx, B. (2021). How effective are hiring subsidies to reduce long-term unemployment among prime-aged jobseekers? Evidence from Belgium. ROA. ROA Research Memoranda No. 005 https://doi.org/10.26481/umaror.2021005

Document status and date:

Published: 04/10/2021

DOI:

10.26481/umaror.2021005

Document Version:

Publisher's PDF, also known as Version of record

Please check the document version of this publication:

- A submitted manuscript is the version of the article upon submission and before peer-review. There can be important differences between the submitted version and the official published version of record.

People interested in the research are advised to contact the author for the final version of the publication, or visit the DOI to the publisher's website.

- The final author version and the galley proof are versions of the publication after peer review.

- The final published version features the final layout of the paper including the volume, issue and page numbers.

Link to publication

\footnotetext{
General rights rights.

- You may freely distribute the URL identifying the publication in the public portal. please follow below link for the End User Agreement:

www.umlib.nl/taverne-license

Take down policy

If you believe that this document breaches copyright please contact us at:

repository@maastrichtuniversity.nl

providing details and we will investigate your claim.
}

Copyright and moral rights for the publications made accessible in the public portal are retained by the authors and/or other copyright owners and it is a condition of accessing publications that users recognise and abide by the legal requirements associated with these

- Users may download and print one copy of any publication from the public portal for the purpose of private study or research.

- You may not further distribute the material or use it for any profit-making activity or commercial gain

If the publication is distributed under the terms of Article $25 \mathrm{fa}$ of the Dutch Copyright Act, indicated by the "Taverne" license above, 


\section{Maastricht University ROA}

How effective are hiring subsidies to reduce long-term unemployment among prime-aged jobseekers?

Evidence from Belgium

Sam Desiere

Bart Cockx

\section{ROA Research Memorandum}

ROA-RM-2021/5

Researchcentrum voor Onderwijs en Arbeidsmarkt | ROA Research Centre for Education and the Labour Market / ROA 


\title{
How effective are hiring subsidies to reduce long-term unemployment among prime-aged jobseekers? Evidence from Belgium
}

\author{
Sam Desiere \\ Bart Cockx \\ ROA-RM-2021/5 \\ September 2021
}

Research Centre for Education and the Labour Market Maastricht University P.O. Box 616, 6200 MD Maastricht, The Netherlands

$\mathrm{T}+31433883647 \mathrm{~F}+31433884914$

secretary-roa-sbe@maastrichtuniversity.nl www.roa.nl 


\section{Abstract \\ How effective are hiring subsidies to reduce long-term unemployment among prime- aged jobseekers? Evidence from Belgium*}

Hiring subsidies are widely used to create (stable) employment for the long-term unemployed. This paper exploits the abolition of a hiring subsidy targeted at long-term unemployed jobseekers over 45 years of age in Belgium to evaluate its effectiveness in the short and medium run. Based on a triple difference methodology the hiring subsidy is shown to increase the job finding rate by $13 \%$ without any evidence of spill-over effects. This effect is driven by a positive effect on individuals with at least a bachelor's degree. However, the hiring subsidy mainly created temporary short-lived employment: eligible jobseekers were not more likely to find employment that lasted at least twelve consecutive months than ineligible jobseekers.

JEL classification: H22, J08, J18, J23, J38, J64, J65, J68

Keywords: hiring subsidies, long-term unemployment, prime-aged jobseekers, triple difference, temporary help agencies

Sam Desiere

Department of Economics

Ghent University

Sint-Pietersplein 6

B-9000 Ghent

Belgium

sam.desiere@ugent.be

\author{
Bart Cockx \\ Department of Economics \\ Ghent University \\ Sint-Pietersplein 6 \\ B-9000 Ghent \\ Belgium \\ bart.cockx@ugent.be \\ and IZA, CESifo, IRES and ROA
}

\footnotetext{
We would like to thank Andrea Albanese and Sofie Cabus for valuable feedback on previous versions. Financial support from VIONA, the Flemish Interuniversity Research Network for Labour Market Reporting, is gratefully acknowledged. The VDAB (the Flemish PES) and the Flemish Department of Work and Social Economy (WSE) supported this project by providing access to the data. These institutions can make the data used in this paper available to researchers wishing to replicate the findings. The statistical code used to generate the results presented in this articles are available on request from the lead author.
} 


\section{Highlights}

- We evaluate a hiring subsidy in Belgium targeted at jobseekers over 45 years of age and unemployed for six months.

- The subsidy increased the job finding rate by $13 \%$.

- The subsidy is more effective for individuals with a least a bachelor's degree.

- The subsidy did not create stable employment, i.e. employment lasting at least 12 (consecutive) months.

- Temporary help agencies obtain a large share of the subsidy, which may explain the findings. 


\section{Introduction}

Long-term unemployment is a persistent challenge of European labour markets. Despite the economic recovery between 2014 and 2020, long-term unemployment remains stubbornly high. Across the EU$28,42.9 \%$ of the jobseekers were unemployed for more than twelve months in $2018 .{ }^{2}$

A popular instrument to fight (long-term) unemployment are hiring subsidies (EC 2019). OECD countries spend $0.08 \%$ of GDP on recruitment incentives, which amounts to $15 \%$ of total spending on active labour market programmes (ALMP). ${ }^{3}$ A more fine-grained analysis ${ }^{4}$ shows that, in 2015, recruitment incentives with specific provisions for the long-term unemployed ${ }^{5}$ were used in 20 out of the 28 EU-countries, while recruitment incentives exclusively targeted at the long-term unemployed were used in 8 countries. In terms of budgets, in 2015, EU-countries spent on average one third of the budget allocated to recruitment incentives on recruitment incentives with at least specific provisions for the long-term unemployed. While comparing programmes across countries is inherently challenging, these figures illustrate that hiring subsidies targeted at the long-term unemployed are common across the $\mathrm{EU}$, which make evaluations of country-specific programmes relevant beyond the specific case that is being evaluated.

This study aims at evaluating the effect of a hiring subsidy in Belgium targeted at jobseekers who are unemployed for at least 6 months and over 45 years of age. This is not the first study that aims at evaluating the impact of such hiring subsidies (see e.g. Sjögren and Vikström 2015; Ciani et al. 2019; Pasquini et al. 2019; and Card et al. 2018 for a survey). However, this study is the first to focus on prime-aged workers in the midst of their career. This subpopulation is of particular interest, as these workers are typically laid-off after accumulating substantial labour market experience and firm specific human capital. There is an ample literature that documents that the displacement costs for such workers are substantial and enduring. ${ }^{6}$ An interesting question is therefore whether hiring subsidies can reverse these costs and be a stepping stone to more stable, permanent positions.

Within the literature evaluating time-limited in-work benefits at the supply side, it is commonly agreed that human capital does not improve by providing short-term work experience to low-skilled welfare recipients inhibiting thereby enduring positive effects on employment and earnings (Blundell 2002 2006; Card and Hyslop 2005; Van der Linden 2021 for a survey). ${ }^{7}$ To the extent that tax incidence is neutral this result is expected to hold as well for demand-side temporary recruitment subsidies. By contrast, for higher educated workers a temporary recruitment subsidy may allow to (re-)build human capital or to reverse the negative signal of long-term unemployment (Cockx and Picchio 2013).

We find that the hiring subsidy increased the job finding rate by $13 \%$. However, we also find that the effect on employment dissipates gradually and becomes zero after a year. Hence, the hiring subsidy

\footnotetext{
${ }^{2}$ Eurostat (indicator: une_Itu_a), accessed April 2020.

${ }^{3}$ https://stats.oecd.org/Index.aspx?DataSetCode=LMPEXP, accessed September 2020.

${ }^{4}$ We are grateful to the OECD for sharing this data. The OECD (2019a) report provides more details of the potential of the Labour Market Policy (LMP) Database to study policies targeted at the LTU; the OECD (2019b) report provides an in-depth evaluation of ALMP targeted at the LTU in five countries.

${ }^{5}$ The OECD defines a long-term unemployed jobseeker as a jobseeker with a continuous spell of unemployment lasting at least a year.

${ }^{6}$ See e.g. Jacobson et al. (1993), Couch and Placzeck (2010), Davis and von Wachter (2011); for some more recent studies: Seim (2019) and Lachowska et al. (2020); and a recent survey: Carrington and Fallick (2017). The latter survey shows that loss of specific human capital is not the only source of the costs due to displacement: it comprises also the loss of job matching, backloaded compensation, of rents, of job contacts, and of mental and physical health, amongst others.

${ }^{7}$ See Riddell and Riddell $(2014,2020)$ for criticism on this view.
} 
does not create long-lasting stable employment. The effect on employment is larger and more persistent for high educated jobseekers with at least a bachelor's degree, but the positive effect also gradually declines over time, suggesting that also for this group it does not extend beyond the expiration of the subsidy. For low-skilled mid-career workers, the level of the wage subsidy may not be high enough to compensate for the loss in firm-specific human capital induced by the job loss. However, we argue that high educated workers have acquired sufficient transferable skills to be hired in short-lived jobs with limited skill requirements. Such jobs can be made acceptable and/or profitable as long as the hiring subsidy is paid out, but not beyond this period. The finding that most of the effect is induced by hiring by temporary work agencies reinforces this interpretation, and is in line with the evidence that the employment offered by these agencies is no stepping stone to more stable employment (Autor and Houseman 2010; Givord and Wilner 2015).

Our findings align to a large extent with the literature on the impact of recruitment subsidies for longterm unemployed workers. According to the well-known review of Card et al. (2018) of 200 studies of ALMP, the long-term unemployed gain more from private sector employment programmes, which typically include hiring subsidies, than other participants. A related paper summarizing the same studies but focusing on the long-term unemployed further emphasises this point (Card et al. 2016). This conclusion is, however, based on only ten studies, of which five are published in academic journals. These studies are listed in Appendix C.

The systematic reviews of Vooren et al. (2019) and Levy-Yeyati et al. (2019) confirm that hiring subsidies in the private sector increase the likelihood of resuming work, but do not report results for the long-term unemployed. The meta-analysis of Filges et al. (2018) also shows that the effect of private sector programs on reemployment tends to be higher than the effect of labour market training, direct employment programs in the public sector or job search assistance, but the differences between these types of ALMP are not statistically significant. The authors note that the number of studies is too low to examine effect heterogeneity across participant characteristics.

Three more recent studies, not included in the aforementioned reviews but closely related to our work, provide further evidence that hiring subsidies targeted at the long-term unemployed have positive effects. Sjögren and Vikström (2015) report positive effects of a hiring subsidy in Sweden targeted at jobseekers unemployed or out of the labour force for at least a year. Importantly, this is the only study that examines the impact of recruitment subsidies on employment stability. In contrast to our findings, they find that hiring subsidies create long-lasting stable jobs. Ciani et al. (2019) and Pasquini et al. (2019) evaluate a hiring subsidy targeted at jobseekers in (Southern) Italy unemployed for at least two years using different identification strategies. Both studies report positive effects on the job finding rate.

Apart from considering a different target population and examining employment stability, our study contributes to the literature in a few other respects. First, our study differs from a methodological perspective in that we rely on a triple difference identification strategy, and that we evaluate the effectiveness of the policy by studying its abolishment rather than its introduction. Furthermore, we study spill-over effects. Scholars have criticized micro-econometric evaluation studies in that they fail to take into account general equilibrium effects, and that a positive employment effect for the target group may merely reflect a countervailing effect on the ineligible population (Crépon et al. 2013; Crépon and van den Berg 2016; Gautier et al. 2018; Cahuc et al. 2018). We study whether the policy benefitted the target group at the expense of slightly younger jobseeker or at the expense of the shortterm unemployed, and do not find any evidence for this. 
The paper is organised as follows. The next section discusses the Belgian institutional setting and the recent labour market reforms. Section 3 describes the data from the Flemish Public Employment Service. Section 4 outlines the triple difference approach. Next, we discuss the effect of the abolition of the hiring subsidy on the transition to employment and on employment stability and examine effect heterogeneity. The final section concludes.

\section{Institutional setting and the policy reform}

\subsection{Long-term unemployment in Flanders}

Belgium is one of the few countries where unemployment insurance (UI) is not time limited, although the benefit level decreases over time. In order to receive UI, a jobseeker has to be registered at one of the four regional Public Employment Services (PES). While the UI is a federal competence, the services provided by the PES such as job counselling, job search monitoring and training are regional competences. More recently, hiring subsidies targeted at disadvantaged groups became a regional competence. This paper focuses on Flanders, the Dutch-speaking region in the north of Belgium.

Since $\mathrm{UI}$ is not time limited, many jobseekers registered at the VDAB (the Flemish PES) are long-term unemployed. In 2019, nearly two thirds of the 184,851 jobseekers were unemployed for more than six months, while half were unemployed for more than one year (Figure 1). From 2014 until the outbreak of the covid-19 pandemic in March 2020, the number of jobseekers continuously decreased.

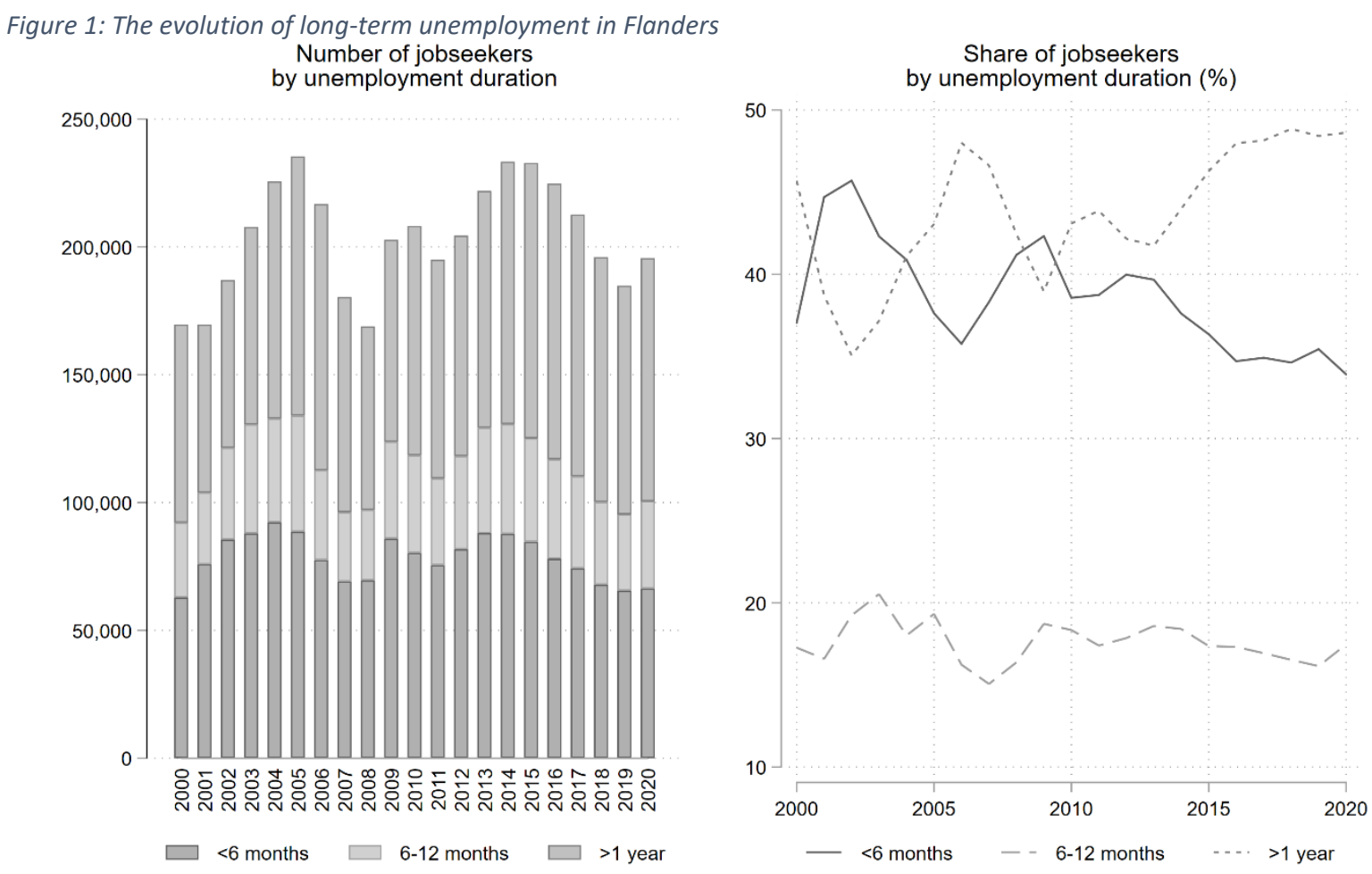

Source: Monthly average from Arvastat (https://arvastat.vdab.be/, accessed April 2021).

It is well-known that the share of the long-term unemployed out of the unemployed population increases during economic booms and decreases during economic recessions (Machin and Manning 1999). This regularity also holds in Flanders. All jobseekers benefitted from the economic recovery from 2014 to 2019, but the positive impact was less pronounced for the long-term unemployed. In $2019,65 \%$ of the jobseekers were unemployed for more than six months, up from $62 \%$ in 2015 . Figure A.3 shows that a similar pattern emerges when restricting the population to jobseekers aged 40 to 48 . As will be explained below, the procyclical behaviour of long-term unemployment is the main reason 
why we opted for a triple difference evaluation strategy rather than a more standard difference-indifferences approach.

The Flemish PES has specific policies tailored to the needs of the long-term unemployed such as training programmes and job counselling (Desiere et al. 2018). Due to a tightening labour market, the PES renewed and reinforced its attention to the long-term unemployed in recent years. In 2017, the PES started to (re)screen jobseekers who were unemployed for more than one year in order to activate them, and launched a new tender for the activation of the long-term unemployed in 2018.

These programmes are unlikely to interfere with the evaluation of the hiring subsidy targeted at jobseekers unemployed for more than six months. First, similar programmes existed before and after the abolition of the subsidy as this aspect of active labour market policies was already a regional competence before the reform. Second, the PES defines a 'long-term unemployed jobseeker' as a jobseeker who is unemployed for at least one year. Our analysis focuses on jobseekers unemployed for one to twelve months. These jobseekers were not eligible for specific programmes aimed at the long-term unemployed.

Until a few years ago, the PES applied specific rules when activating and monitoring jobseekers over 50 years of age. Moreover, this group was eligible for a more generous hiring subsidy until 2014. We restrict the population to jobseekers aged 40 to 48 to avoid that these specific policies for older jobseekers interfere with our evaluation of the hiring subsidy. The PES did not have specific programmes in place aimed at jobseekers aged 40 to 48 over the entire period considered in the analyses.

Just like the hiring subsidies, job search monitoring also became a regional competence and was subsequently reformed. Since 2016 job search monitoring in Flanders is the competence of the PES, and no longer of a separate federal institution. It is unlikely that the reform of the job search monitoring interferes with the evaluation of the abolition of the hiring subsidy because job search monitoring already occurred before the reform, was not or, at best, only gradually intensified after the reform and did not specifically target jobseekers unemployed for more than six months.

\subsection{Hiring subsidies targeted at the long-term unemployed}

In 2014 wage and hiring subsidies targeted at disadvantaged groups became a regional competence. All four Belgian regions subsequently reformed and simplified the complex existing federal system of wage and hiring subsidies and substantially reduced the number of eligible groups. Flanders opted to abolish all hiring subsidies targeted at the long-term unemployed. This paper focuses on the abolition of the hiring subsidy targeted at jobseekers over 45 years of age who were unemployed for at least six months over the past nine months. After the reform, jobseekers in Flanders aged 25 to 55 were no longer eligible for any hiring subsidy.

Until January 1, 2017, employers hiring older, long-term unemployed jobseekers were entitled to a quarterly Social Security contribution (SSC) reduction of $€ 1,000$ during the first five quarters, followed by a quarterly reduction of $€ 400$ during the subsequent sixteen quarters. Hence, the total maximum hiring subsidy amounted to $€ 11,400$ over 21 quarters. The subsidies were reduced (almost proportionally) for employees working part time.

The hiring subsidies were not automatically awarded to the employers. Eligible jobseekers had to obtain a certificate from a federal institution proving their eligibility. Employers could then use this certificate to obtain SSC reductions. Eligible individuals (or their employer) could still apply for this certificate after they had been hired, but the subsidies were not granted retrospectively. Given data 
limitations, the take-up rate of the hiring subsidy is unknown, but the take-up rate of similar SSC reductions is estimated to be approximately 70\% (Boucq and Novella 2018; Desiere et al. 2020).

From January 1, 2017 no new certificates were awarded to Flemish jobseekers, in effect abolishing the hiring subsidy in Flanders. The subsidies granted under the federal rules were gradually phased out. Jobseekers who had obtained a certificate before January 1, 2017 remained eligible for the hiring subsidy until the certificate expired. Employers who had hired an eligible jobseeker continued to receive subsidies until the end of 2018.

In the last quarter of 2016, 2,564 individuals benefitted from the hiring subsidy in Flanders, of whom 369 individuals were hired in that quarter. The average, quarterly subsidy amounted to $€ 506$, while the total yearly cost of the policy amounted to $€ 5,3$ million in 2016 .

The median full-time equivalent gross monthly wage (which excludes SSC paid by the employer) of individuals hired with a subsidy is $€ 2,324$, and ranges for half of these employees between $€ 1,981$ ( $3^{\text {rd }}$ quartile) and $€ 2,796$ ( $1^{\text {st }}$ quartile). Their income is lower because only one out of four individuals work full-time. Taking the aforementioned interquartile range as measure of spread, the abolition of the subsidy increased labour costs by $11 \%$ to $16 \%$ during the first five quarters after being hired and by at most $6 \%$ during the sixteen subsequent quarters. ${ }^{8}$

\section{Data}

The dataset consists of all jobseekers who registered at the VDAB (the Flemish PES) between January 2012 and December 2018. The monthly labour market position of each jobseeker is known from registration until February 2019. This position is determined on the last day of each month. The administrative data distinguish several types of employment (e.g. sheltered work, part-time work in combination with unemployment benefits) that are linked to the administrative status of the jobseeker. The dataset does not contain details on the sector of employment, the type of contract, the wage, or the number of days worked. We adopted VDAB's standard definition of employment, but also considered a more stringent definition of work that excludes, among others, temporary help agency jobs lasting between 10 and 20 days per month.

An unemployment spell starts in the month of registration at the PES and ends when the jobseeker resumes work. In the benchmark analysis jobseekers who leave the labour force at a certain point in time are still considered unemployed. ${ }^{9}$ The findings are robust to censoring unemployment spells when jobseekers leave the labour force (Table A.7).

The dataset contains socio-economic characteristics of jobseekers such as date of birth, level of education, language proficiency and nationality. We restrict the population to jobseekers entitled to $\mathrm{UI}$ aged 40 to 48 at the time of registration at the PES, excluding jobseekers aged 44 . As we will discuss in the next section, the treatment group consists of long-term unemployed jobseekers aged 45 to 48 , while all the other jobseekers belong to the control group. Jobseekers aged 44 are excluded from the

\footnotetext{
${ }^{8}$ These estimates do not take into account the so-called 'Tax Shift' which gradually reduced employers' SSC, particularly for low-wage workers (irrespectively of their prior unemployment duration or age), from 2016 to 2019. The tax shift partially offsets the negative impact of the abolition of the hiring subsidy on labour costs. After accounting for the tax shift, the abolition of the subsidy increased the labour cost by $8 \%$ at the median wage.

${ }^{9}$ We opted for this approach because jobseekers classified by the Flemish PES as 'out of the labour force' might still be actively looking for a job, while jobseekers classified as 'actively looking for a job' might in practice be out of the labour force.
} 
sample because some of the jobseekers in this age group become eligible for the subsidy after being unemployed for six to twelve months.

Prior to the reform, jobseekers were eligible for a hiring subsidy after being unemployed for at least six months in the previous nine months. Eligibility for a hiring subsidy is stipulated by law and closely monitored by a federal institution. Because we will compare the job finding rate of the short-term to the long-term unemployed, we have to identify the exact point in time a jobseeker becomes eligible for a subsidy, but the time grouping of the unemployment data in months prevent us from determining this point for all jobseekers in the population. To address this issue, we retain in the sample only individuals who were registered as employed for at least four consecutive months prior to registration at the PES. This approach avoids that some jobseekers become eligible for the subsidy prior to the six months threshold after registration, since at registration such workers can at most be five months unemployed in the last nine months, which is less than the required six months for eligibility.

This restriction implies that unemployment spells that started between January 2012 and April 2012 (i.e. the first four months in the dataset) are discarded, because it cannot be checked whether these individuals were employed prior to registration at the PES. Of the remaining 189,154 unemployment spells, 14,556 spells are discarded because the labour market history in the past four months is not known, whereas 69,365 spells are discarded because the jobseeker did not work four consecutive months prior to registration. ${ }^{10}$ Finally, 796 spells are discarded because the jobseeker's self-reported proficiency in Dutch, which is one of the covariates in the regressions, is missing. The final dataset contains 78,536 unique individuals who account for 104,437 unemployment spells.

The first two columns of Table 1 compare the characteristics of jobseekers aged 45 to 48 before and after the reform. The pre-reform and post-reform period contain jobseekers who registered at the PES before and after June 1, 2016, respectively. Overall, these jobseekers are vulnerable in several respects. About eight out of ten have at most a lower-secondary (low) or at most an upper-secondary (medium) level of education; only about half report having an excellent proficiency in Dutch; and one out of five were born outside the EU-28.

The triple difference identification strategy, discussed below, requires that the composition of the population before and after the reform is stable. This is the case. Jobseekers before and after the reform have fairly similar characteristics. The main difference between both groups is that the population of jobseekers in the pre-reform period are more likely to be born in the EU-15 $(80.2 \%$ versus $73.8 \%$ ) and tend to be more proficient in Dutch.

The last three columns of Table 1 present the characteristics of long-term unemployed jobseekers aged 45 to 48 , i.e. jobseekers who are still unemployed six months after registration at the PES, in the pre-reform and post-reform period and of the long-term unemployed hired with a subsidy. Their characteristics are determined at the time of registration at the PES. A first observation is that longterm unemployed jobseekers are generally more vulnerable than the population of jobseekers aged 45 to 48 (column 3 versus column 1 and column 4 versus column 2), which includes jobseekers who

\footnotetext{
10 The PES only registers someone's labour market position after an individual has registered at the PES. We discarded 14,556 spells because these individuals were not known by the PES prior to becoming unemployed. These individuals were (most likely) employed or out of the labour force prior to registration at the PES and one could assume that these individuals only became eligible for the subsidy six months after registration. We nevertheless discarded this group because we could not explicitly check that this eligibility condition was met. In Table A.6, we show that the main findings hold when including this group. We also show that our findings are robust to including jobseekers who did not work four consecutive months prior to becoming unemployed.
} 
will quickly resume work, but the differences are not particularly pronounced. In both periods, the long-term unemployed are more likely to have a low level of education and tend to be less proficient in Dutch. The second observation is that individuals hired with the subsidy appear not to be 'selected' based on observable socio-economic characteristics. Jobseekers hired with a subsidy (column 5) have similar characteristics as the long-term unemployed (column 3). If anything, individuals hired with a subsidy even tend to have a lower level of education.

We only observe the sector of employment for individuals hired with a subsidy. The temporary help agency sector is by far the most important sector: over a period of almost two years $61 \%$ of the jobseekers who resumed work with a subsidy were hired by temporary help agencies. The second most important sector, the cleaning sector, only accounts for $5 \%$ of the hires (Table A.1). In each quarter, $38 \%$ and $7 \%$ of all subsidised employees are employed by temporary help agencies and by the cleaning sector, respectively (Table A.2). The discrepancy between the share of new hires by temporary help agencies and the share of subsidised employees at a given moment in this sector indicates that subsidised jobs in the temporary help agency sector are less stable than in other sectors.

Table 1: Characteristics of all jobseekers aged 45 to 48 vs. the long-term unemployed in the same age group

\begin{tabular}{|c|c|c|c|c|c|}
\hline & \multicolumn{2}{|c|}{ Jobseekers, aged 45 to 48} & \multicolumn{3}{|c|}{ Long-term unemployed, aged 45 to 48} \\
\hline & Before the reform & After the reform & Before the reform & After the reform & Hired with a subsidy ${ }^{1}$ \\
\hline Age & 46.47 & 46.47 & 46.48 & 46.46 & 47.13 \\
\hline Men & $53.80 \%$ & $54.84 \%$ & $54.83 \%$ & $54.13 \%$ & $56.84 \%$ \\
\hline \multicolumn{6}{|l|}{ Education } \\
\hline Low & $37.47 \%$ & $38.53 \%$ & $44.15 \%$ & $41.56 \%$ & $43.33 \%$ \\
\hline Medium & $42.73 \%$ & $39.37 \%$ & $36.41 \%$ & $37.10 \%$ & $43.73 \%$ \\
\hline High & $19.80 \%$ & $22.11 \%$ & $19.44 \%$ & $21.34 \%$ & $12.94 \%$ \\
\hline \multicolumn{6}{|l|}{ Proficiency in Dutch } \\
\hline No proficiency & $1.07 \%$ & $2.58 \%$ & $1.20 \%$ & $2.71 \%$ & $2.22 \%$ \\
\hline Limited proficiency & $10.06 \%$ & $13.08 \%$ & $11.79 \%$ & $15.48 \%$ & $9.61 \%$ \\
\hline Good proficiency & $39.04 \%$ & $35.13 \%$ & $39.50 \%$ & $35.32 \%$ & $37.60 \%$ \\
\hline Excellent proficiency & $49.83 \%$ & $49.21 \%$ & $47.51 \%$ & $46.50 \%$ & $50.57 \%$ \\
\hline \multicolumn{6}{|l|}{ Origin } \\
\hline EU-15 & $80.16 \%$ & $73.80 \%$ & $76.42 \%$ & $70.15 \%$ & $77.97 \%$ \\
\hline EU-13 & $1.76 \%$ & $2.97 \%$ & $1.95 \%$ & $3.35 \%$ & $3.11 \%$ \\
\hline Other & $18.08 \%$ & $23.23 \%$ & $21.63 \%$ & $26.50 \%$ & $18.92 \%$ \\
\hline \# individuals & 30,405 & 18,587 & 16,381 & 7,192 & 1,221 \\
\hline
\end{tabular}

Note: EU-15: Austria, Belgium, Denmark, Finland, France, Germany, Greece, Ireland, Italy, Luxembourg, the Netherlands, Portugal, Spain, Sweden and the United Kingdom. EU-13 (new EU member states): Bulgaria, Croatia, Cyprus, Czech Republic, Estonia, Hungary, Latvia, Lithuania, Malta, Poland, Romania, Slovakia and Slovenia. Low level of education: at most lower secondary education; medium level: upper secondary education or post-secondary non-tertiary education; high level: short-cycle tertiary education, bachelor's level, master's level or doctoral level.

${ }^{1}$ This column presents characteristics of individuals aged 45 to 48 hired with a subsidy between the second quarter of 2015 and the last quarter of 2016 (pre-reform period). We do not have this information for jobseekers hired before 2015 because we obtained data from Flemish institutions who are in charge of this policy since 2015 and only have data since then. We excluded the first quarter of 2015 because we present the characteristics of the new hires, not of the population of subsidised employees at a given moment in time.

Descriptive evidence shows that subsidised jobs are not long-lasting. The share of employees for whom a subsidy was granted for several subsequent quarters quickly decreases with employment duration. About $70 \%$ of the individuals for whom a subsidy was granted in a first quarter also received a subsidy in the second quarter, while approximately $25 \%$ received a subsidy during four consecutive quarters. This illustrates that a large majority of subsidised jobs is destroyed after a few quarters. Jobs 
in the temporary help agency sector are less stable than jobs in other sectors. Only $63 \%$ of jobseekers hired with a subsidy by this sector are still employed with a subsidy in the next quarter compared to $79 \%$ of the jobseekers hired by other sectors.

Figure 4 explores the employment stability of individuals over 45 years of age hired before the reform after being unemployed for five (full line) and six months (dashed line). Only individuals in the latter group are eligible for the subsidy. It shows the share of individuals employed for 1 to 65 consecutive months after being hired. Employment tends to be short-lived. Half of the individuals are employed for less than ten consecutive months, while one in four is employed for at least five years. Although the differences are small and not statistically significant at conventional levels, the figure suggests that individuals hired without a subsidy have more stable employment spells than individuals hired with a subsidy. Individuals employed with and without a subsidy are equally likely to remain employed for five consecutive months. However, after being employed for five months, individuals employed with a subsidy are more likely to lose their job.

However, this is just descriptive evidence which cannot be given any causal interpretation. In the next section we discuss the strategy that is followed to identify causal effects.

Figure 2: Employment stability: share of individuals hired in month 5 (not eligible for the subsidy) vs. month 6 (eligible for the subsidy) employed for 1 to 65 consecutive months after being hired

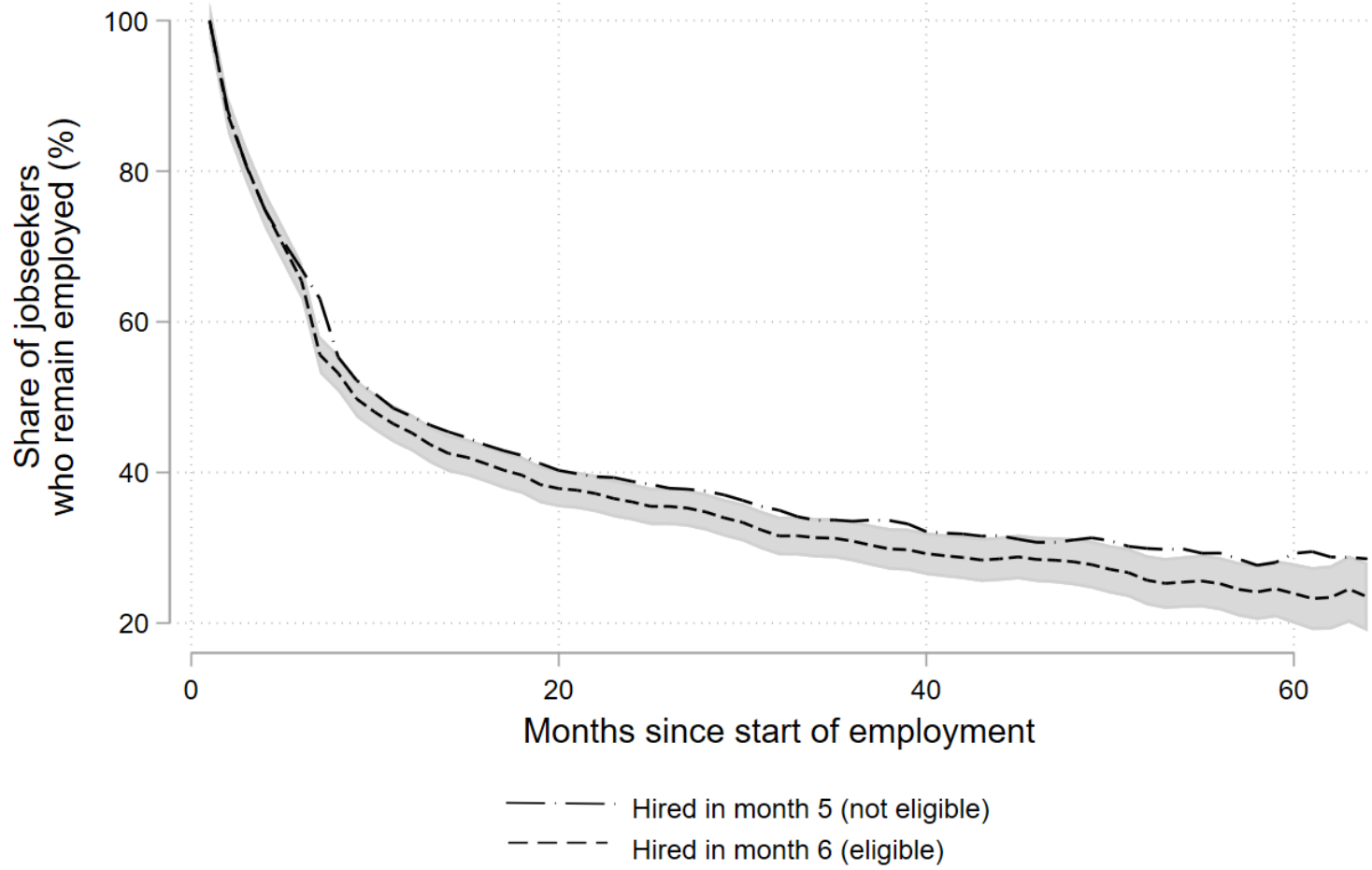

Note: For clarity only the $95 \% \mathrm{Cl}$ for individuals hired in month 6 are shown. The main message is that the employment rate of individuals hired in month 5 (not eligible for the subsidy) is slightly higher than the employment rate of individuals hired in month 6 (eligible for the subsidy), but the difference between both groups is not statistically significant. The $\mathrm{Cl}$ are constructed by regressing the employment rate on the number of months after registration (dummies), the two age groups (40-43 vs. 45-48), and their interaction terms.

\section{Identification strategy}

We aim at estimating the effect of the abolition of the hiring subsidy on the transition to employment and on employment stability of long-term unemployed jobseekers. Our basic set-up follows a triple difference approach (Gruber 1994; Olden and Møen 2020; Wing et al. 2018). This approach exploits differences in labour market prospects between short-term (unemployed for less than six months) and long-term unemployed jobseekers (unemployed for six to twelve months), across age groups 
(jobseekers aged 40 to 43 vs jobseekers aged 45 to $48^{11}$ ) and between periods (before and after the reform).

The following linear probability model is estimated:

$$
\begin{gathered}
y_{\text {imt }}=M_{m}+\beta_{1} D_{t}+\beta_{2} A_{i}+\delta_{1}\left(I_{m} * D_{t}\right)+\delta_{2}\left(A_{i} * I_{m}\right)+\delta_{3}\left(A_{i} * D_{t}\right)+\lambda\left(A_{i} * D_{t} * I_{m}\right)+\eta X_{i}+\text { year }_{t} \\
+\epsilon_{i m t} \text { with } m \epsilon[1,12]
\end{gathered}
$$

where $y_{i m t}$ is the outcome of interest (i.e. the job finding rate or an indicator of employment stability) of jobseeker $i$ who registered at the PES in calendar month $t$ and has been unemployed for $m$ months. $D_{t}$ takes respectively the value 0 and 1 if individual $i$ became unemployment before or after June 1 , 2016. ${ }^{12}$ Put differently, $D_{t}$ equals 0 before the reform, i.e. when older jobseekers are eligible for hiring subsidies after being unemployed for six months. $I_{m}$ indicates whether the jobseeker has been unemployed for at least six months, while $A_{i}$ indicates whether the jobseeker is over 45 years of age at the time of registration at the PES. The variable $M_{m}$ models (negative) duration dependence. $X_{i}$ is a vector of the jobseekers' characteristics, year $_{t}$ denotes the year the jobseeker became unemployed and $\epsilon_{i j t}$ is the error term. By including the year when the jobseeker registered at the PES, we implicitly control for the business cycle at the time of inflow in unemployment.

We examine employment outcomes for jobseekers unemployed for one to twelve months, and censor unemployment spells after twelve months. We do not consider the employment prospects of jobseekers unemployed for more than twelve months because this group was eligible for even more generous hiring subsidies before the reform.

The parameter of interest, $\lambda$, indicates how labour market prospects of long-term unemployed jobseekers over 45 years of age changed due to the abolition of the subsidy. Since we study the abolition of a subsidy intended to improve labour market prospects, $\lambda$ is expected to be negative. Like previous authors (Pasquini et al. 2019; Schünemann et al. 2015; Sjögren and Vikström 2015), we focus on the effect of being eligible for the subsidy, regardless of the actual take-up.

We estimate a triple difference, rather than a difference-in-differences (DiD), because the parallel trends of the DiD are rejected, as will be shown in Section 5.1 below. By contrast, the weaker identifying assumptions of a triple difference are not rejected. The identifying assumption of a triple difference is that the parallel trend in differences holds (Olden and Møen 2020). In other words, in the absence of the treatment, the difference between the outcome for long-term versus short-term unemployed jobseekers below 45 years of age must trend similarly as the same difference for jobseekers over 45 years of age. Importantly, the triple difference estimator will not be biased if the business cycle affects the long-term unemployed differently than the short-term unemployed as long as the differential effect of the business cycle on short versus long-term unemployed is similar for jobseekers younger and older than 45 .

Our approach differs from the standard difference-in-differences and triple difference method because we exploit the abolition of the subsidy to identify the Average Treatment Effect on the

\footnotetext{
11 Jobseekers aged 44 to 44.5 at the time of registration at the PES are excluded because these jobseekers are not yet eligible at the six months threshold, but will become eligible after six to twelve months. Jobseekers aged 44.5 to 45 belong in theory to the treatment group, as these jobseekers will be eligible after being unemployed for six months. We nevertheless excluded them because these jobseekers might be less aware of the existence of the subsidy or might be less likely to apply for a certificate immediately after turning 45 years old. Including the 44.5 to 45 years old in the treatment group does not alter the main findings (Table A.7).

${ }^{12}$ The subsidy was abolished on January 1, 2017. Hence, jobseekers who registered at the PES after June 1, 2016 are never eligible for the subsidy.
} 
Treated (ATT) rather than exploiting the introduction of a subsidy, which is more common. In our setup, the control group is never treated (as is standard), while the treatment group is treated in the prereform period and is not treated in the post-reform period. The post-reform period is thus the period during which both the treatment and control group are not treated, while this state of the world typically occurs in the pre-reform period in the standard setting. This implies that the parallel trend assumption should hold in the post-reform period (when both groups are not treated) and not necessarily in the pre-reform period (when the treatment group is treated). We will report placebotests for the post-reform period. As an additional placebo test, we will also examine whether the job finding rate of the short-term unemployed remained unaffected by the reform.

One additional concern with our approach is bias due to dynamic sorting. The linear probability model is a robust estimator of the average partial effect in settings with discrete duration data (Angrist 2001), but only holds in the absence of unobserved individual effects (see e.g. Farbmacher and Tauchmann 2021). Unobserved individual effects cause dynamic sorting because individuals with a higher unobserved 'ability' are more likely to quickly resume work and, hence, leave the sample. One way to test for the presence of unobserved individual effects is to check whether the grouped residuals are autocorrelated over time. Dynamic sorting leads to negative autocorrelation. We will follow Cockx and Ridder (2001) and test for this autocorrelation based on the Breusch-Godfrey LM test of autocorrelation.

Like in difference-in-differences specifications, substitution and anticipation effects can bias the triple difference estimate. We will examine whether (1) long-term unemployed were hired at the expense of the short-term unemployed; (2) whether older jobseekers were hired at the expense of younger jobseekers; and (3) whether the last eligible cohorts of jobseekers were hired at the expense of the first ineligible cohorts.

We first examine the effect of the subsidy on the job finding rate. In this case, the outcome variable, $y_{\text {imt }}$, is an indicator that is equal to one if a jobseeker unemployed up to month $m-1$ resumes work in month $m$, and zero otherwise. This definition corresponds to a hazard rate so that the unemployment spell ends when the jobseeker resumes work. In this case the estimated parameter of interest $\hat{\lambda}$ measures in percentage points the extent to which the subsidy facilitates the transition to employment of the long-term unemployed.

After establishing the positive effect of the subsidy on the job finding rate, we examine whether the subsidy created short-lived or long-lasting, stable employment. ${ }^{13}$ To this end, we re-estimate equation 1, but use different outcome variables. First, we use a more stringent definition of employment, thereby excluding short-lived temporary help agency work. Second, we define indicators which capture employment stability. These indicators are hazard rates: they are equal to zero as long as the jobseekers does not start an employment spell that meets a certain condition, equal 1 if this condition is met and are not defined thereafter. We define twelve indicators which are equal to one if employment is found that lasts $X$ consecutive months, whereby $X$ ranges from 1 to $12 .{ }^{14}$ Hence, the first indicator is one if the jobseeker finds employment (which corresponds to the basic specification), the second indicator equals one if the jobseekers finds employment that lasts at least two consecutive months, etc. We also experimented with alternative indicators. Rather than requiring that an employment spell lasts $X$ consecutive month, these alternative indicators take the value 1 if a

\footnotetext{
${ }^{13}$ We do not observe job-to-job transitions without an intervening unemployment spell. For this reason, the paper focuses on employment stability, not on job stability or on job tenure.

14 The indicator is only defined if the total time span is within the observed period, i.e. until February 2019. Hence, the regressions contain fewer observations when considering longer employment durations.
} 
jobseekers is being employed for $\mathrm{X}$ months over a twelve months period after being hired. This is a slightly less demanding definition of employment stability since it does not require continuous employment in the next twelve months after being hired. These alternative indicators allow testing whether short-lived employment spells serve as stepping stones to other (short-lived) spells within the next twelve months.

\section{Results}

\subsection{Difference-in-differences vs triple difference}

Given the setting, it would be natural to estimate the abolition of the subsidy in a difference-indifferences framework, either contrasting short to long-term unemployed older jobseekers, or jobseekers below to those over 45 years of age among the long-term unemployed.

Figure 3 illustrates the former approach and shows the job finding rate of jobseekers aged 45 to 48 in function of elapsed unemployment duration before and after the reform. The impact of the abolition of the subsidy appears evident. Due to the improved economic conditions the job finding rate is higher for the "control" unemployment durations in 2017 than in 2015, but the job finding rate abruptly decreases in 2017 at the moment the jobseeker would have become eligible for the subsidy before the reform. Reassuringly, such a 'jump' in the job finding rate is not observed for jobseekers aged 40 to 43 (Figure A.1), which suggests that the jump observed here can be attributed to the abolition of the subsidy.

Figure 3: Exploring the effect of the abolition of the subsidy in a difference-in-differences framework: the job finding rate of jobseekers aged 45 to 48 in function of elapsed unemployment duration, before and after the reform

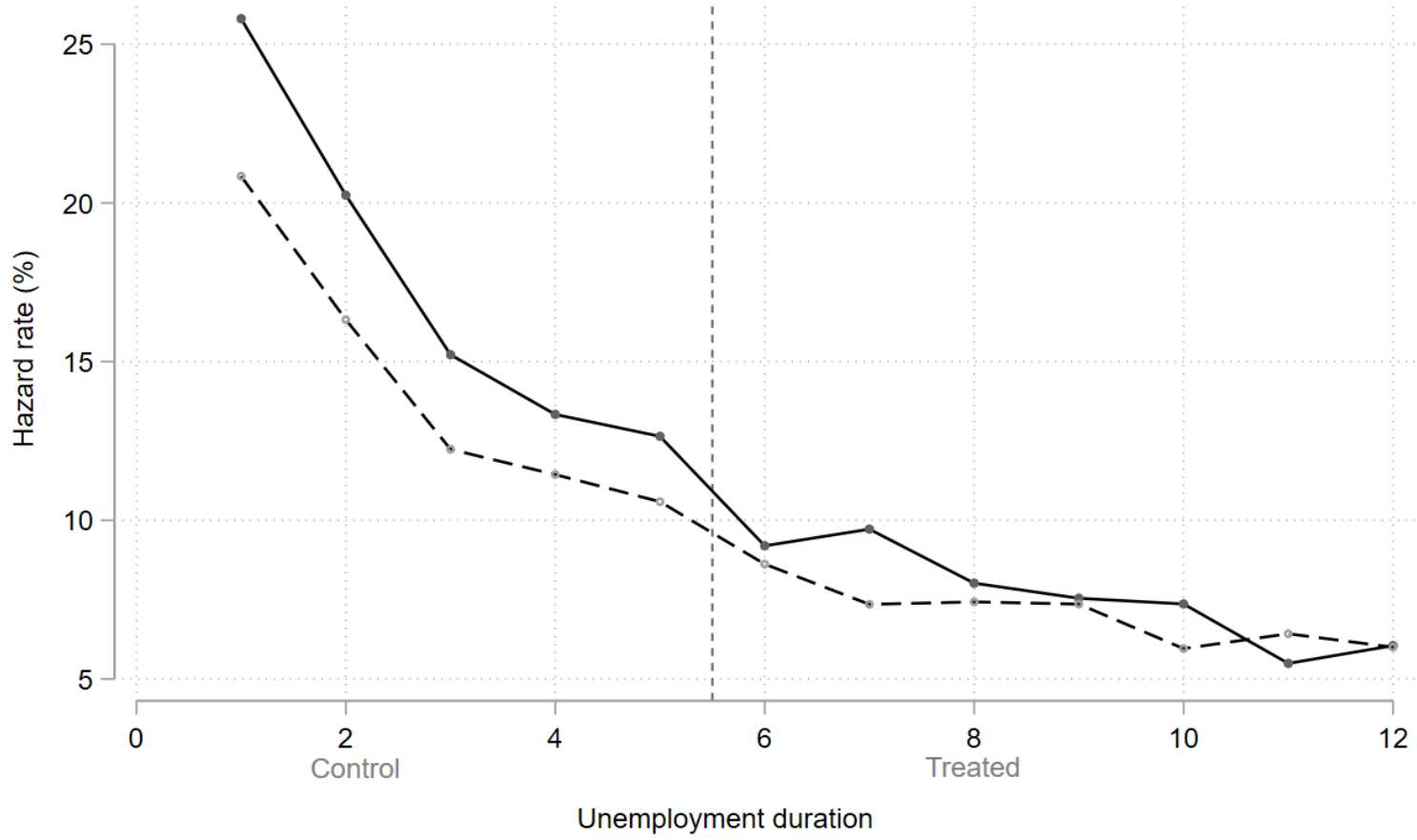

\footnotetext{
$\rightarrow$ After the reform

- - Before the reform
}

Note: The vertical dashed line indicates the month jobseekers become eligible for the hiring subsidy prior to the reform. The pre-reform period consists of jobseekers who registered at the PES in 2015. The post-reform period consists of jobseekers who registered in 2017.

Formal DiD estimates are reported in Appendix B. Contrasting short to long-term unemployed older jobseekers, as in Figure 3, suggests that the abolition of the subsidy decreased the job finding rate by 3.52 percentage points [ $95 \% \mathrm{Cl}:-4.03-3.00]$. The DiD model exploiting differences across age 
groups, rather than across unemployment duration, suggests that the abolition of the subsidy reduced the job finding rate by 0.14 percentage points [ $95 \% \mathrm{Cl}:-0.62-0.34]$. Hence, the abolition of the subsidy has a substantial negative effect on the job finding rate when exploiting differences across unemployment duration, but the effect is close to zero when exploiting differences across age groups.

Appendix B presents placebo-tests which reject the validity of both DiD approaches. The business cycle biases both approaches in opposite directions. Economic upswings have a stronger positive effect on the short-term than on the long-term unemployed, a well-known finding in the literature (Machin and Manning 1999). Hence, comparing the job finding rate of short to long-term unemployed older jobseekers (as in Figure 3 ) overestimates the negative effect of the abolition of the subsidy since it does not capture that, relative to the short-term unemployed, the job finding rate of the long-term unemployed would have deteriorated anyway after the reform due to the improved economic conditions. At the same time, we find evidence that the job prospects of all jobseekers aged 45 to 48 , including the short-term unemployed who were not affected by the reform, improved more than those of younger jobseekers after the reform, most likely because the improved economic conditions were more beneficial to older than younger jobseekers. Hence, contrasting the job finding rate of younger to older long-term unemployed jobseekers underestimates the negative effect of the abolition of the subsidy.

The triple difference approach captures these business cycle effects and avoids wrongly attributing them to the abolition of the subsidy. The weaker identifying assumption of a triple difference, as we show below, are not rejected. The first regression in Table 2 estimates the benchmark specification. The triple interaction term in the first specification indicates that the abolition of the subsidy reduced the job finding rate by 1.18 [ $95 \% \mathrm{Cl}: 0.48-1.88$ ] percentage points. This is a relatively large effect. Given that the job finding rate after being unemployed for six months is $9.2 \%$ after the reform, the hiring subsidy increased the job finding rate by $13 \%$ [95\% Cl: $5 \%-20 \%]$. We also tested whether the effect on the job finding rate varied by unemployment duration (Table A.7). While the effect appears to decrease with unemployment duration, a formal F-test rejects that these differences are statistically significant at the $5 \%$ level.

Other studies evaluating hiring subsidies targeted at the long-term unemployed also report positive effects on the job finding rate. The results cannot be directly compared since the targeted population, the take-up rate, the subsidy amount and the subsidy duration differ. Sjögren and Vikström (2015) report that a hiring subsidy in Sweden targeted at jobseekers unemployed or out of the labour force for at least a year increased the job finding rate by $5.8 \%$. This was the finding for the case that the payroll tax (31.4\%) was no longer due for a duration equal to their time in unemployment or out of the labour force, thereby decreasing labour costs on average by $24 \%$ during this period. Doubling the subsidy or doubling the duration of the subsidy increased the job finding rate by $28 \%$ and $65 \%$, respectively. Ciani et al. (2019) and Pasquini et al. (2019) evaluate a subsidy targeted at jobseekers in (Southern) Italy unemployed for at least two years using different identification strategies. This hiring subsidy covered $50 \%$ to $100 \%$ of the payroll tax of $32.7 \%$ for three years, thereby reducing labour costs by $12 \%$ to $25 \%$. Ciani et al. (2019) report that the subsidy increased the weekly chance of finding a permanent job by $41 \%$, while, according to Pasquini et al. (2019), the subsidy increased the job finding rate by $36 \%$.

In order to make the findings of these studies more comparable, we calculate the elasticity of the transition from unemployment to employment with respect to the labour cost. The Belgian hiring subsidy reduced the labour cost by $13 \%$ at the median wage level and increased the transition to employment by $13 \%$ [95\% Cl: $5 \%-20 \%$ ], so that the elasticity equals -1 [ $95 \% \mathrm{Cl}:-1.54--0.38$ ]. Similar calculations yield an estimate of this elasticity in Italy of -2.2 and -2.5 , respectively for the study of 
Pasquini et al. (2019) and Ciani et al. (2019). By contrast, in Sweden the elasticities are -0.24 for the single subsidy and -0.59 for the double subsidy. While these are crude estimates that warrant careful interpretation, they nevertheless indicate that our estimates are in-between those for Sweden and Italy, and that that hiring subsidies targeted at long-term unemployed are effective, at least in terms of the hiring rate. However, as we will discuss in Section 5.3, this effectiveness is transitory.

Table 2: The impact of the abolition of the hiring subsidy on the job finding rate-Triple difference estimates

\begin{tabular}{|c|c|c|c|c|c|}
\hline & \multirow[t]{2}{*}{ Benchmark } & \multicolumn{3}{|c|}{ Ruling out: } & \multirow{2}{*}{$\begin{array}{c}\text { More stringent } \\
\text { definition of 'work' } \\
\text { (excluding short-lived } \\
\text { temporary work) }\end{array}$} \\
\hline & & $\begin{array}{c}\text { Substitution } \\
\text { between age } \\
\text { groups }\end{array}$ & $\begin{array}{c}\text { Substitution } \\
\text { between the short- } \\
\text { term and long-term } \\
\text { unemployed }\end{array}$ & $\begin{array}{l}\text { Anticipation } \\
\text { effects }\end{array}$ & \\
\hline $\begin{array}{l}\text { Age 45-48y \#\# post-reform \#\# long- } \\
\text { term unemployed (base level } 40-43 y \text { ) }\end{array}$ & $-0.0118 * * *$ & & $-0.0119 * * *$ & $-0.0133 * * *$ & $-0.00636 * *$ \\
\hline \multicolumn{6}{|l|}{$\begin{array}{l}\text { Post-reform \#\# long-term unemployed } \\
\text { (base level 35-37y) }\end{array}$} \\
\hline \#\# age 38y & & $\begin{array}{l}0.00779 * * \\
(0.00389)\end{array}$ & & & \\
\hline \#\# age 39y & & $\begin{array}{l}0.000466 \\
(0.00394)\end{array}$ & & & \\
\hline$\# \#$ age $40 y$ & & $\begin{array}{l}0.00170 \\
(0.00399)\end{array}$ & & & \\
\hline \#\# age 41y & & $\begin{array}{l}-0.00158 \\
(0.00404)\end{array}$ & & & \\
\hline$\# \#$ age $42 y$ & & $\begin{array}{l}0.00222 \\
(0.00413)\end{array}$ & & & \\
\hline \#\# age 43y & & $\begin{array}{l}-0.000159 \\
(0.00410)\end{array}$ & & & \\
\hline \#\# age 44-44.5y & & $\begin{array}{l}0.000781 \\
(0.00558)\end{array}$ & & & \\
\hline $\begin{array}{l}\text { Age } 45-48 \text { y\# post-reform \#\# } \\
\text { unemployed for five months }\end{array}$ & & & $\begin{array}{l}-0.000716 \\
(0.00667) \\
\end{array}$ & & \\
\hline \# Unemployment spells & 104,437 & 281,701 & 104,437 & 89,291 & 104,437 \\
\hline \# Observations & 602,916 & $1,686,890$ & 602,916 & 516,196 & 753,119 \\
\hline $\mathrm{R}^{2}$ & 0.032 & 0.033 & 0.032 & 0.032 & 0.013 \\
\hline $\begin{array}{l}\text { Placebo tests } \\
\text { Post-reform parallel trend test (F-test, } \\
\text { p-value) } \\
\text { Effect on the short-term unemployed } \\
\text { (p-value) }\end{array}$ & 0.84 & 0.93 & 0.75 & 0.86 & 0.91 \\
\hline
\end{tabular}

Note: Results of the estimating the triple differences regressions as specified by equation (1). The benchmark specification contrasts the job finding rate across age groups (40-43 vs 45-48 years old), unemployment duration (unemployed for 1 to 5 months vs unemployed for 6 to 12 months) and period (before vs after the reform). The other triple difference regressions rule out substitution and anticipation effects by respectively using jobseekers aged 35 to 37 as the control group, using jobseekers unemployed for 1 to 4 months as the control group and by excluding jobseekers who registered as unemployed in 2016 from the regression. The last triple difference regression follows the same specification as the benchmark, but uses a more stringent definition of 'work', thereby excluding temporary agency work lasting between 10 and 20 days per month. The following control variables are included in all regressions: unemployment duration (dummies), year of registration at the PES, level of education (low, medium, high), self-reported proficiency in Dutch, region of origin and sex. Full results of the benchmark specification are reported in Table A.3. The placebo-tests verify whether the parallel trends assumption holds in the post-reform period and whether the abolition of the subsidy did not affect the job finding rate of jobseekers unemployed for five months (see also Table A.4). Huber-White standard errors robust for heteroskedasticity in parentheses. $* * *, * * *$ denote statistical significance at the $1 \%, 5 \%$ and $10 \%$ level, respectively. 
At the bottom of Table 2, we report the results of two placebo tests. First, we test whether the job finding rate evolved in parallel in treatment and control group in the post-reform period. This approach corresponds to pretending that the reform took place in a 'placebo' year after the reform (e.g. in 2017 rather than in 2016), and testing whether the triple interaction term is insignificant in this case. As explained above, the credibility of our DiD approach requires that the parallel trend in the post-reform period - when both treatment and control group are not treated - holds. This is the case. ${ }^{15}$ The second placebo-test examines whether the job finding rate of the short-term unemployed is unaffected by the reform. It tests whether the job finding rate of jobseekers unemployed for less than five months has changed relative to the job finding rate of jobseekers unemployed for exactly five months. This placebo-test shows that the reform did not affect the job finding rate of the shortterm unemployed, thereby further confirming the validity of the triple difference approach.

To rule out bias due to dynamic sorting, we test for autocorrelation based on the Breusch-Godfrey LM test of autocorrelation. To this end, the population is split in groups using all possible combinations of the explanatory variables included in the regression and the average error in each group is calculated. The grouped error is regressed on the lagged grouped error and the explanatory variables using the inverse of variance of the dependent variable as weights (Table A.8). We find a small, but significant positive autocorrelation of 0.053 . The presence of a small positive autocorrelation, rather than negative autocorrelation, indicates that dynamic sorting does not bias our findings and justifies the choice of a linear probability model. It also implies that jobseekers aged 40 to 48 are a homogenous population, with little unobserved heterogeneity among jobseekers.

\subsection{Substitution and anticipation effects}

The triple difference exploits differences across unemployment duration, age and time periods. Substitution and anticipation effects can bias the triple difference estimates. Regression 2 to 4 in Table 2 examine and rule out that the presence of substitution or anticipation effects bias the findings. This also indicates the absence of general equilibrium effects: the positive effects on the job finding rate of the target group are not at the expense of ineligible groups.

First, we consider eight age groups to examine whether, prior to the reform, employers hired older jobseekers eligible for the hiring subsidy at the expense of younger jobseekers. Using the triple difference approach, we evaluate whether the job finding rates of jobseekers younger than 44.5 years improved after the abolition of the subsidy. To do so, we examine the job finding rate of jobseekers by age in the age group 38 to 44 years to the job finding rate of jobseekers aged 35 to 37 . Under the assumption that the substitutability decreases with the age differential, then, if substitution effects matter, the positive effect of the subsidy on the older eligible unemployed will be at the expense of the job finding rate of those below the eligibility threshold, and, more so the closer the age is to the eligibility threshold. For this reason, we also included jobseekers aged 44 to 44.5 in the regressionsa group excluded in the baseline specification - because this age group is just below the age eligibility threshold, and, therefore, most likely to be negatively affected by the hiring subsidy. There is no evidence that the job finding rate of jobseekers just below the eligibility threshold improved after the abolition of the hiring subsidy (Table 2, regression 2).

\footnotetext{
${ }^{15}$ The parallel trend also holds in the pre-reform period, which indicates that the effectiveness of the hiring subsidy is not sensitive to the business cycle. This is noteworthy because recent studies have found that wage and hiring subsidies are more effective during downturns (Benzarti and Harju 2021) and in regions with higher levels of unemployment (Saez et al. 2021).
} 
Second, we examine whether, prior to the reform, the long-term unemployed were hired at the expense of the short-term unemployed. Again, we find no evidence of these substitution effects. The job finding rate of jobseekers aged 45 to 48 and unemployed for five months did not improve after the abolition of the subsidy relative to the job finding rate of jobseekers in the same age group unemployed for less than five months (Table 2, regression 3). This indicates that employers did not hire the long-term unemployed at the expense of jobseekers who were just below the eligibility threshold.

Third, we rule out anticipation effects by excluding jobseekers who became unemployed in 2016 from the regressions. Jobseekers who registered in the first two quarters of 2016 remained eligible for a hiring subsidy until the end of 2018, whereas jobseekers who registered during the last two quarters of 2016 were never eligible for the subsidy. Employers may have tried to hire the last cohort of eligible jobseekers at the expense of the first cohort of ineligible jobseekers. Excluding jobseekers registered in 2016 from the regressions does not, however, alter the main findings (Table 2, regression 4).

\subsection{Employment stability}

While the subsidy increased the job finding rate of the long-term unemployed, the question remains whether the subsidy successfully created stable employment. Descriptive evidence presented earlier indicates that subsidised employment tends to be short-lived. Moreover, search and matching models predict that hiring subsidies increase job creation and job destruction, leading to less stable jobs (Kaas and Kircher 2015; Mortensen and Pissarides 2001). Most previous studies have not focused on employment stability, although creating stable jobs is often an explicit objective of hiring subsidies. One notable exception is Sjögren and Vikström (2015) who present evidence that workers holding a subsidised jobs are more likely to keep their job even after the subsidy expires. A recent evaluation of a payroll tax cut for young workers in Sweden also find persistent effects after the workers age out of eligibility and even after the abolition of the policy (Saez et al. 2021).

To test the effect of the subsidy on employment stability, we again rely on the triple difference approach, but use different outcome variables. We first use a more stringent definition of 'employment', which excludes temporary help agency work. Next, we define two related outcome variables which capture employment stability. The first outcome is defined as finding a job and remaining employed for 1 to 12 consecutive months after being hired, while the second outcome is defined as finding a job and being employed for 1 to 12 (not necessarily consecutive months) in the next twelve months after being hired. The second indicator allows us to test whether short-lived employment spells created by the subsidy serve as a stepping stone to other (short-lived) employment spells within the next twelve months.

As mentioned earlier, the Flemish PES records different types of 'work'. The regressions presented so far consider any type of employment as a positive outcome. The fifth regression in Table 2 uses a more stringent definition of work which excludes several types of atypical work, most importantly temporary help agency work that lasted between 10 and 20 days per month. Excluding atypical work as a positive outcome halves the triple interaction term to -0.6 percentage points, but the effect remains statistically significant at the $5 \%$ level. This is a first indication that the hiring subsidy mainly created short-lived employment, and had a more limited effect on the creation of more stable employment.

To further examine employment stability, we redefine the outcome as finding a job and remaining employed for several (consecutive) months in the next twelve months after being hired, again including all types of work. Figure 4 visualises the results of the triple difference regressions for both 
outcomes. The subsidy has a more pronounced effect on finding short-lived employment than on longer-lasting employment. The effect of the abolition of the subsidy converges towards zero with increasing employment duration. While the abolition of the subsidy reduced the likelihood of being employed for at least one month by 1.18 percentage points, the abolition reduced the likelihood of being employment for at least 6 and 12 consecutive months by 0.41 and 0.05 percentage points, respectively. This is in line with the graphical evidence presented in Figure 2 which suggested that the employment trajectories of individuals hired with a subsidy were less stable than those of individuals hired without a subsidy.

Figure 4: The effect of the abolition of the subsidy on the probability of finding employment lasting 1 to 12 (consecutive) months
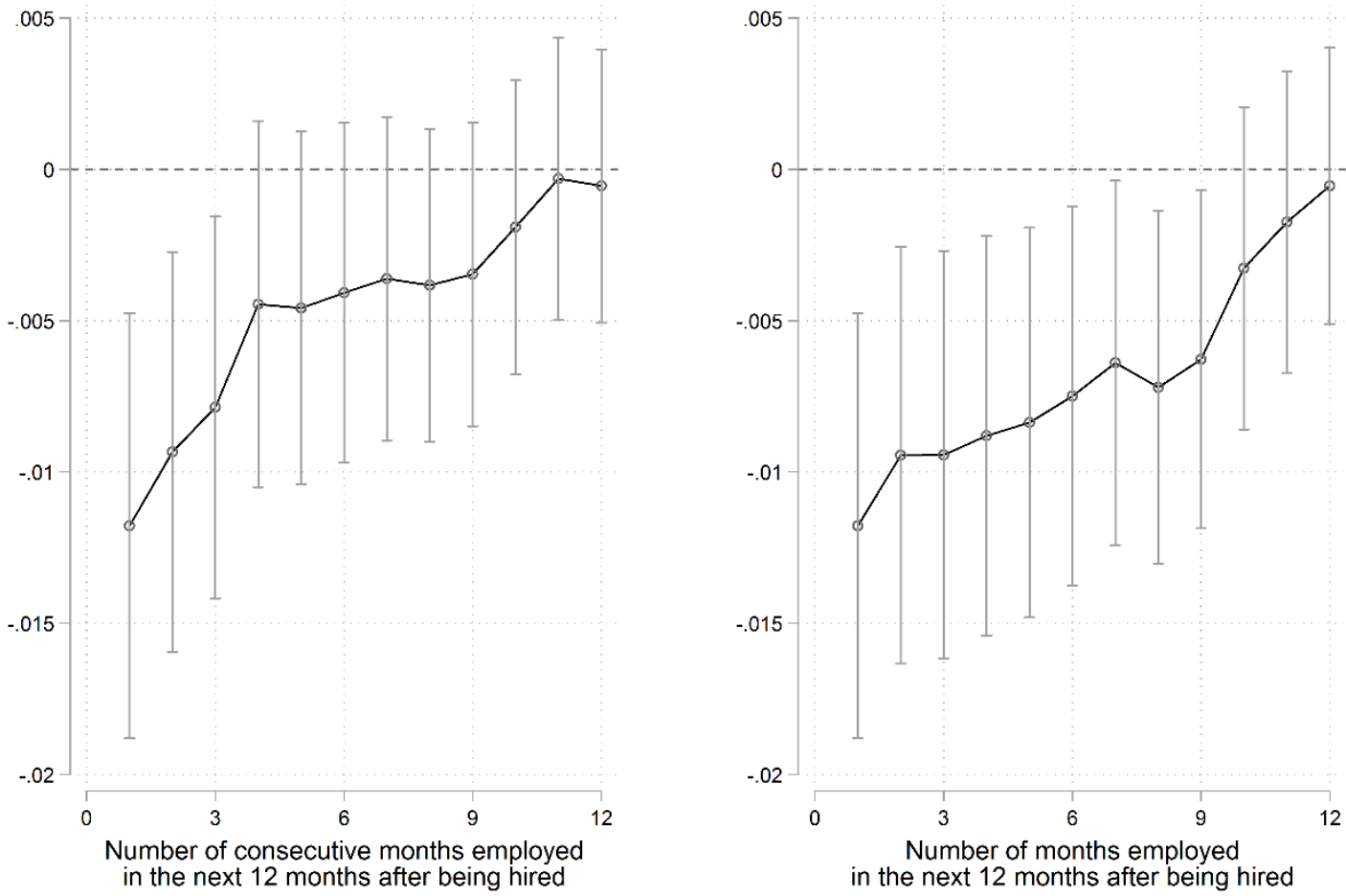

Note: Each graph shows the triple interaction term with its $95 \% \mathrm{Cl}$ obtained by estimating twelve triple difference regressions following the benchmark specification as in Table 2. The outcome is an indicator taking the value 1 if the jobseeker found a job and remained employed for 1 to 12 (consecutive) months, and zero otherwise. Full results of the triple difference regressions are reported in Table A.5.

The abolition of the subsidy has only a slightly larger effect on the number of months worked (not necessarily consecutive) over a twelve months period after being hired (Figure 4, right panel) than on the number of consecutive months worked over the same period (Figure 4, left panel). Hence, the short-lived employment spells created by the subsidy do not serve as stepping stones to other employment spells in the next twelve months.

The results remain qualitatively similar when using the more stringent definition of employment (Figure A.2). While the subsidy's effect on the job finding rate are more limited when excluding atypical work, the effect of the subsidy on stable employment still tends towards zero for employment spells that lasts at least 12 (consecutive) months.

\subsection{Effect heterogeneity}

In this section, we examine whether certain groups of jobseekers benefitted more from the hiring subsidy. We explore effect heterogeneity along two dimension: gender and level of education. These dimensions are important for three reasons. First, systematic reviews of active labour market programmes often report estimates along these dimensions. For instance, the review of Card et al. 
(2018) report a larger impact for women and for disadvantaged groups. Second, we will compare our findings with those of Sjögren and Vikström (2015) who report larger effects for long-term unemployed men and long-term unemployed individuals without university education. Third, a heterogeneity analysis can shed light on the underlying mechanism explaining the results.

Table 3 examines the effect of the abolition of the subsidy on the job finding rate and on employment stability by gender and level of education. The hiring subsidy is more effective for jobseekers with at least a bachelor's degree. It also appears to be more effective for women than men, but the difference between men and women is not statistically significant (Table 3, col 1) ${ }^{16}$ For jobseekers with at least a bachelor's degree, the subsidy increases the job finding rate by 2.6 percentage points (pp), whereas the effect size is only $0.7 \mathrm{pp}$ for the lower educated group. ${ }^{17}$ The pattern is qualitatively similar when using a more stringent definition of work as the outcome (Table 3, col 2), but the impact of the subsidy is then less than half as large for the high educated group ( $+1.1 \mathrm{pp})$, suggesting that more than half of the effect is induced by enhanced hiring in very short-lived temporary jobs. The impact is also smaller for the lower educated group ( $0.5 \mathrm{pp}$ ), but the effect declines less, so that the effect difference between the lower and higher educated group is no longer statistically significant at the $10 \%$ level.

For all groups the effect of the subsidy decreases with employment duration, confirming that the subsidy did not create stable employment (Table 3, col 3). For the higher educated the effect is still significantly positive for remaining employed six consecutive months, but it is only $60 \%$ of its effect on the job finding rate, and it further decreases to $35 \%$ of this effect (not reported in Table 3 ) when considering twelve instead of six consecutive months. Unfortunately, as the subsidy can last as long as 21 quarters the data do not allow to check whether the effect for the higher educated group converges to zero after the subsidy expires, but the pattern of the effect does suggest this.

Table 3: The effect of the subsidy by gender and level of education

\begin{tabular}{lccc}
\hline & Job finding rate & Job stability \\
\hline & $\begin{array}{c}\text { Benchmark } \\
\text { specification }\end{array}$ & $\begin{array}{c}\text { More stringent } \\
\text { definition of 'work' } \\
\text { (excluding short- } \\
\text { lived temporary } \\
\text { work) }\end{array}$ & $\begin{array}{c}\text { Remaining employed for six } \\
\text { consecutive months }\end{array}$ \\
\hline Sex & & -0.0048 & -0.0044 \\
Men & -0.0076 & $(0.0039)$ & $(0.0039)$ \\
Women & $(0.0118)$ & $-0.0083^{* *}$ & $(0.0041$ \\
Education & $-0.0168^{* * *}$ & $(0.0038)$ & $\left.-0.0005^{\mathrm{a}}\right)$ \\
Less than a bachelor's degree & $(0.0052)$ & $-0.0051^{*}$ & $(0.0032)$ \\
At least a bachelor's degree & $-0.0074^{*}$, a & $(0.003)$ & $-0.0163^{* *, a}$ \\
& $(0.004)$ & $-0.0113^{*}$ & $(0.0064)$ \\
\hline
\end{tabular}

Note: The table shows the triple interaction term obtained by estimating triple difference regressions on different subsamples following the benchmark specification as in Table 2 . Huber-White standard errors robust for heteroskedasticity in parentheses. $* * *, * *, *$ denote statistical significance at the $1 \%, 5 \%$ and $10 \%$ level, respectively. The letter ' $a$ ' indicates statically significant differences between estimates within the same column under the same heading at the $5 \%$ level. For instance, in the first column the effect on jobseekers without a bachelor's degree is significantly different from the effect on jobseekers with at least a bachelor's degree.

Our findings are the opposite of those of Sjögren and Vikström (2015) who report larger effects for individuals without a university education, and also for men. They interpret these findings as suggestive evidence that the private sector, which tends to employ more men, is more responsive to the policy, and that labour demand is more sensitive at the lower end of the pay distribution which explains why the hiring subsidy is more beneficial to lower-educated workers. The latter explanation

16 The post-reform placebo tests also hold for each of the subsamples. This rules out that the effect heterogeneity observed here can be attributed to a failure of the parallel trend for specific groups.

${ }^{17}$ We grouped jobseekers with a low and medium level of education because we did not observe differences between these groups. 
is not relevant in our setting because wages of individuals with a bachelor degree hired with the subsidy have only slightly higher wages than individuals without a bachelor degree (mean monthly gross wage of $€ 2,489 \mathrm{vs} € 2,139$ ), presumably as a consequence of the relatively high minimum wages in Belgium (see e.g. Rycx and Kampelmann (2013)), and that dismissed workers among the high educated are more negatively selected than among the low educated.

We see the following explanations for our findings. First, our analysis focuses on laid-off 'mid-career' individuals. At this stage of the career job loss usually goes in pair with substantial losses in firmspecific labour market experience and human capital. Consequently, the wage subsidy and the temporary spells of employment cannot compensate for this loss, making it hard without retraining to materialize an enduring - lasting beyond the subsidization period - labour market reintegration. The finding that higher educated workers are more likely to be temporarily hired than lower educated workers thanks to the subsidy could be related to their acquisition of more general, transferable, skills: this makes them more likely to be hired in different jobs than those from which they were laid-off; the subsidy may compensate for the higher wage costs that are required to make these jobs acceptable, or make up for the productivity gap linked to the reallocation.

Second, we already highlighted that the subsidies were mainly used by temporary help agencies. Out of all hires with a subsidy, roughly $60 \%$ were hired by temporary help agencies. It is noteworthy that groups that traditionally rely more on the services of temporary help agencies, namely (men and) lower-educated jobseekers, are also the groups that benefitted less from the subsidy. The subsidies seem to have provided a windfall profit for temporary help agencies which would anyway have offered temporary jobs to low-educated jobseekers. However, without a subsidy the hiring of jobseekers with a university degree did not seem profitable for these agencies. By the above argument, the wage subsidy could therefore create additional employment for these workers. However, this employment is not long-lasting or does not seem to be a stepping stone to other, more persistent employment, probably because temp work is not skill enhancing, and may even stigmatize workers (Autor and Houseman 2010; Givord and Wilner 2015). This is in line with the findings of Cockx and Van Belle (2019) and Cockx et al. (2020), who report that in Belgium temp work does not cause long-lasting employment for unemployed youth.

\section{Conclusion}

Using a triple difference approach, this paper studies the effectiveness of a hiring subsidy targeted at jobseekers over 45 years of age and unemployed for at least six months. The subsidy increases the job finding rate by $13 \%$. This corresponds to an elasticity of the transition of unemployment to employment with respect to the labour cost of -1 , which is in-between the estimates from evaluations of hiring subsidies targeted at the long-term unemployed in Sweden and Italy.

However, the subsidy mainly created temporary employment and had a more limited effect on entering stable employment, i.e. employment that lasted several months. The effect of the subsidy gradually decreased with the duration of the employment spell, and the subsidy did not improve the likelihood of finding employment that lasted at least twelve (consecutive) months. Most subsidised employment spells were destroyed after a few quarters, well before the subsidy expired. Moreover, the subsidy was more effective for individuals with at least a bachelor's degree, while jobseekers without a bachelor's degree did not benefit from the subsidy.

These findings are in line with the hypothesis that the displacement costs of job loss for these midcareer workers are so substantial that a temporary subsidy is insufficient for an enduring reintegration on the labour market. It therefore remains an open question which type of policies can be successful 
for this target group. In view of the involved substantial loss in skills and the specificity of these skills, it seems natural that such policies should involve some education or training to provide these workers with the necessary skills to relocate to a new industry (Jacobsen et al. 2011). A number of studies finds supportive evidence for this. Jacobsen et al. (2005a, 2005b) show that enrolment in community college education can dramatically improve the long-term earnings prospects of displaced workers aged 35 or older in the US. Similarly, Picchio and Van Ours (2013) find positive effects of training on the employment prospects of older workers. Cockx et al. (1998), evaluating labour market policies in Belgium from the '90s, showed that subsidised on-the-job training created more stable employment than pure hiring subsidies. For this target group the evaluation of programmes with a training content is therefore a promising direction for future research.

\section{References}

Angrist, J. D. (2001). Estimation of limited dependent variable models with dummy endogenous regressors: Simple strategies for empirical practice. Journal of Business \& Economic Statistics, 19(1), $2-28$.

Autor, D.H., Houseman, S. N. (2010). Do temporary-help jobs improve labor market outcomes for lowskilled workers? Evidence from "Work First". American Economic Journal: Applied Economics, 2(3), 96-128.

Benzarti, Y., Harju, J. (2021). Can payroll tax cuts help firms during recessions? Journal of Public Economics, 2021, 104472.

Blundell, R. (2002). Welfare-to-work: Which policies work and why? Keynes Lecture in Economics: Proceedings of the British Academy, 117, 477-524.

Blundell, R. (2006). Earned income tax credit policies: Impact and optimality: The Adam Smith Lecture, 2005. Labour Economics, 13(4), 423-443.

Boucq, E., Novella, M. L. (2018). Non-take-up van werkgeversbijdrageverminderingen: het geval van de maatregel 'eerste aanwervingen'. Federaal Planbureau.

Cahuc, P., Carcillo, S., Le Barbanchon, T. (2018). The effectiveness of hiring credits. The Review of Economic Studies, 86(2), 593-626.

Card, D., \& Hyslop, D. R. (2005). Estimating the effects of a time-limited earnings subsidy for welfareleavers. Econometrica, 73(6), 1723-1770.

Card, D., Kluve, J., Weber, A. (2016). Active labour market policies and long-term unemployment. In Long-Term Unemployment After the Great Recession: Causes and Remedies. CEPR Press.

Card, D., Kluve, J., Weber, A. (2018). What works? A meta analysis of recent active labor market program evaluations. Journal of the European Economic Association, 16(3), 894-931.

Carrington, W. J., and Bruce F. (2017). Why do earnings fall with job displacement? Industrial Relations, $56(4), 688-722$.

Ciani, E., Grompone, A., Olivieri, E. (2019). Long-term unemployment and subsidies for permanent employment. Bank of Italy. Working Paper.

Cockx, B., Declercq, K., Dejemeppe, M., Inga, L., Van der Linden, B. (2020). Switching from an inclining to a zero-level unemployment benefit profile : good for work incentives?, Labour Economics, 64, 101816. 
Cockx, B., Picchio, M. (2013). Scarring effects of remaining unemployed for long-term unemployed school-leavers. The Journal of the Royal Statistical Society: Series A (Statistics in Society), 176(4), 951-980.

Cockx, B., Ridder, G. (2001). Social employment of welfare recipients in Belgium: An evaluation. The Economic Journal, 111(470), 322-352.

Cockx, B., Van Belle, E. (2019). Waiting longer before claiming, and activating youth: no point?, International Journal of Manpower, 40(4), 658-687.

Cockx, B., Van der Linden, B. , Karaa, A. (1998). Active labour market policies and job tenure. Oxford Economic Papers, 50(4), 685-708.

Couch, K. A., Placzek, D.W. 2010. Earnings losses of displaced workers revisited. American Economic Review, 100 (1), 572-89.

Crépon, B., Duflo, E., Gurgand, M., Rathelot, R., Zamora, P. (2013). Do labor market policies have displacement effects? Evidence from a clustered randomized experiment. The Quarterly Journal of Economics, 128(2), 531-580.

Crépon, B., Van Den Berg, G. J. (2016). Active labor market policies. Annual Review of Economics, 8, 521-546.

Davis, S. J., von Wachter., T. (2011). Recessions and the Costs of Job Loss. Brookings Papers on Economic Activity (Fall): 1-55.

Desiere, S., Cabus, S., Cockx, B. (2020). Een evaluatie van het Vlaamse doelgroepenbeleid. HIVA KU Leuven.

Desiere, S., Van Landeghem, B., Struyven, L. (2018). Wat het beleid aanbiedt aan wie: een onderzoek bij Vlaamse werkzoekenden naar vraag en aanbod van activering. HIVA KU Leuven.

DWSE. (2018). Vlaams doelgroepenbeleid: Jaarrapport 2017. Departement Werk en Sociale Economie.

EC. (2019). Evaluation of the Council Recommendation on the integration of the long-term unemployed into the labour market. European Commission.

Farbmacher, H., Tauchmann, H. (2021). Linear fixed-effects estimation with non-repeated outcomes. FAU Discussion Papers in Economics.

Filges, T., Smedslund, G., Jørgensen, A.-M. K. (2018). Active labour market programme participation for unemployment insurance recipients: A systematic review. Research on Social Work Practice, 28(6), 653-681.

Gautier, P., Muller, P., van der Klaauw, B., Rosholm, M., Svarer, M. (2018). Estimating equilibrium effects of job search assistance. Journal of Labor Economics, 36(4), 1073-1125.

Givord, P., Wilner, L. (2015). When does the stepping-stone work? Fixed-term contracts versus temporary agency work in changing economic conditions. Journal of Applied Econometrics, 30(5), 787-805.

Gruber, J. (1994). The incidence of mandated maternity benefits. American Economic Review, 622641.

Jacobson, L. S., LaLonde, R. J., Sullivan, D. G. (1993). Earnings losses of displaced workers. American Economic Review, 83 (4), 685-709.

Jacobson, L. S., LaLonde, R. J., Sullivan, D. G. (2005a). Estimating the returns to community college schooling for displaced workers. Journal of Econometrics, 125, 1-2,271-304. 
Jacobson, L. S., LaLonde, R. J., Sullivan, D. G. (2005b). The impact of community college retraining on older displaced workers: should we teach old dogs new tricks? Industrial and Labor Relations Review, 58, 3, 98-415

Jacobson, L. S., LaLonde, R. J., Sullivan D. G. (2011). Policies to reduce high-tenured displaced workers' earnings losses through retraining. The Hamilton Project Discussion Paper.

Kaas, L., \& Kircher, P. (2015). Efficient firm dynamics in a frictional labor market. American Economic Review, 105(10), 3030-60.

Lachowska, M., Mas, A., Woodbury, S. A. (2020). Sources of workers' long-term earnings losses. American Economic Review, 110(10), 3231-3266.

Levy-Yeyati, E., Montané, M., Sartorio, L. (2019). What works for active labor market policies? CID Working Paper Series.

Machin, S., Manning, A. (1999). The causes and consequences of long-term unemployment in Europe. Handbook of Labor Economics, 3, 3085-3139.

Mortensen, D. T., Pissarides, C. A. (2001). Taxes, subsidies and equilibrium labour market outcomes. CEPR Discussion Paper No. 2989.

OECD (2019a). LMP interventions for the long term unemployed: an initial assessment. OECD: Paris.

OECD (2019b). LMP interventions for the long term unemployed: in-depth evaluation. OECD: Paris.

Olden, A., Møen, J. (2020). The Triple Difference Estimator. NHH Dept. of Business and Management Science Discussion Paper(2020/1).

Pasquini, A., Centra, M., Pellegrini, G. (2019). Fighting long-term unemployment: Do we have the whole picture? Labour Economics, 61, 101764.

Picchio, M., Van Ours, J. C. (2013). Retaining through training even for older workers. Economics of Education Review, 32, 29-48.

Riddell, C., \& Riddell, W. C. (2014). The pitfalls of work requirements in welfare-to-work policies: Experimental evidence on human capital accumulation in the Self-Sufficiency Project. Journal of Public Economics, 117, 39-49.

Riddell, C., \& Riddell, W. C. (2020). Interpreting Experimental Evidence in the Presence of Postrandomization Events: A Reassessment of the Self-Sufficiency Project. Journal of Labor Economics, 38(4), 873-914.

Rycx, F., Kampelmann, S. (2013). Who earns minimum wages in Europe? New evidence based on household surveys. CEB Working Paper.

Saez, E., Schoefer, B., Seim, D. (2021). Hysteresis from employer subsidies. Journal of Public Economics, 200, 104459.

Schünemann, B., Lechner, M., Wunsch, C. (2015). Do long-term unemployed workers benefit from targeted wage subsidies? German Economic Review, 16(1), 43-64.

Seim, D. (2019). On the incidence and effects of job displacement: Evidence from Sweden. Labour Economics, 57, 131-145.

Sjögren, A., Vikström, J. (2015). How long and how much? Learning about the design of wage subsidies from policy changes and discontinuities. Labour Economics, 34, 127-137.

Van der Linden, B. (2021). Do in-work benefits work for low-skilled workers? IZA World of Labor, 246. 
Vooren, M., Haelermans, C., Groot, W., Maassen van den Brink, H. (2019). The effectiveness of active labor market policies: A meta-analysis. Journal of Economic Surveys, 33(1), 125-149.

Wing, C., Simon, K., Bello-Gomez, R. A. (2018). Designing difference in difference studies: best practices for public health policy research. Annual review of public health, 39. 


\section{Appendix A: Additional Tables \& Figures}

Table A.1: The five most important sectors in terms of new hires with a subsidy in each quarter (2015Q2-2016Q4)

\begin{tabular}{lr}
\hline Sector & $\begin{array}{c}\text { Share of new hires with } \\
\text { a subsidy, 2015Q2-16Q4 }\end{array}$ \\
\hline Temporary employment agency activities & $61 \%$ \\
Cleaning activities & $4 \%$ \\
Restaurants and mobile food service activities & $2 \%$ \\
Retail sale in non-specialised stores & $2 \%$ \\
Other social work activities without accommodation & $2 \%$ \\
\hline
\end{tabular}

Note: Sector classified based on the NACE-3 digit classification.

Table A.2:Distribution of subsidised workers by sector at a given quarter (2015Q1-2016Q4)

\begin{tabular}{lr}
\hline Sector & Share of subsidised employees \\
\hline Temporary employment agency activities & $38 \%$ \\
Cleaning activities & $7 \%$ \\
Other social work activities without accommodation & $3 \%$ \\
Retail sale of other goods in specialised stores & $3 \%$ \\
Retail sale in non-specialised stores & $2 \%$ \\
\hline
\end{tabular}

Note: Sector classified based on the NACE-3 digit classification. 
Table A.3: The impact of the abolition of the hiring subsidy on the job finding rate, full results of the benchmark specification

\begin{tabular}{|c|c|}
\hline & Benchmark \\
\hline \multicolumn{2}{|l|}{ Unemployment duration (base level: month 1) } \\
\hline Month 2 & $\begin{array}{c}-0.0407^{* * *} \\
(0.00183)\end{array}$ \\
\hline Month 3 & $\begin{array}{c}-0.0841^{* * *} \\
(0.00181)\end{array}$ \\
\hline Month 4 & $\begin{array}{c}-0.0998^{* * *} \\
(0.00183)\end{array}$ \\
\hline Month 5 & $\begin{array}{c}-0.109 * * * \\
(0.00185)\end{array}$ \\
\hline Month 6 & $\begin{array}{c}-0.111^{* * *} \\
(0.00213)\end{array}$ \\
\hline Month 7 & $\begin{array}{c}-0.122 * * * \\
(0.00213)\end{array}$ \\
\hline Month 8 & $\begin{array}{l}-0.129 * * * \\
(0.00213)\end{array}$ \\
\hline Month 9 & $\begin{array}{l}-0.132 * * * \\
(0.00214)\end{array}$ \\
\hline Month 10 & $\begin{array}{c}-0.141 * * * \\
(0.00212)\end{array}$ \\
\hline Month 11 & $\begin{array}{l}-0.141^{* * *} \\
(0.00215)\end{array}$ \\
\hline Month 12 & $\begin{array}{c}-0.143^{* * *} \\
(0.00217)\end{array}$ \\
\hline Post-reform & $\begin{array}{c}0.0250^{* * *} \\
(0.00275)\end{array}$ \\
\hline Age 45-48y & $\begin{array}{c}-0.00487^{* * *} \\
(0.00144)\end{array}$ \\
\hline Age $45-48 y$ \#\# post-reform & $\begin{array}{c}0.0101 * * * \\
(0.00261)\end{array}$ \\
\hline Post-reform \#\# long-term unemployed & $\begin{array}{c}-0.0231^{* * *} \\
(0.00247)\end{array}$ \\
\hline Post-reform \#\# age 45-48y \#\# long-term unemployed & $\begin{array}{c}-0.0118 * * * \\
(0.00358)\end{array}$ \\
\hline \multicolumn{2}{|l|}{ Year of registration at the PES (base level: 2012) } \\
\hline 2013 & $\begin{array}{c}-0.00498 * * * \\
(0.00147)\end{array}$ \\
\hline 2014 & $\begin{array}{c}0.00309^{* *} \\
(0.00154)\end{array}$ \\
\hline 2015 & $\begin{array}{c}0.0131 * * * \\
(0.00159)\end{array}$ \\
\hline 2016 & $\begin{array}{c}0.0115 * * * \\
(0.00205)\end{array}$ \\
\hline 2017 & $\begin{array}{c}0.0162 * * * \\
(0.00283)\end{array}$ \\
\hline 2018 & $\begin{array}{c}0.0205^{* * *} \\
(0.00298)\end{array}$ \\
\hline \multicolumn{2}{|l|}{ Education (base level: high level) } \\
\hline Low & $\begin{array}{c}-0.00236^{* *} \\
(0.00116)\end{array}$ \\
\hline Medium & $\begin{array}{c}0.00423^{* * *} \\
(0.00115)\end{array}$ \\
\hline Man & $\begin{array}{c}0.00759^{* * *} \\
(0.000845)\end{array}$ \\
\hline \multicolumn{2}{|l|}{ Proficiency in Dutch (base level: no proficiency) } \\
\hline Limited proficiency & $\begin{array}{c}-0.00967^{* * *} \\
(0.00332)\end{array}$ \\
\hline Good proficiency & $\begin{array}{c}0.00455 \\
(0.00325)\end{array}$ \\
\hline Excellent proficiency & $\begin{array}{c}0.00491 \\
(0.00329)\end{array}$ \\
\hline Origin (base level: EU-15) & \\
\hline EU-13 & $\begin{array}{c}-0.0196^{* * *} \\
(0.00261)\end{array}$ \\
\hline Other & $\begin{array}{c}-0.0250^{* * *} \\
(0.00110)\end{array}$ \\
\hline Constant & $0.197 * * *$ \\
\hline
\end{tabular}


$(0.00387)$

\# Unemployment spells

104,437

\# Observations

602,916

$\mathrm{R}^{2} \quad 0.032$

Note: Huber-White standard errors robust for heteroskedasticity in parentheses. ${ }^{* * *}, * *,{ }^{*}$ denote statistical significance at the $1 \%, 5 \%$ and $10 \%$ level, respectively. 
Age 45-48y \#\# long-term unemployed \#\#

2012

0.00494

(0.00613)

2013

0.00441

(0.00534)

2014

$-0.000794$

(0.00559)

2016 Q1-Q2

0.00574

(0.00762)

2016 Q3-Q4

$-0.00516$

$(0.00715)$

2017

$-0.0101^{*}$

(0.00616)

2018

$-0.0137^{*}$

(0.00721)

Age 45-48y \#\# after reform \#\# unemployed for (base level: 5 months)

Less than 5 months

6 to 12 months

\begin{tabular}{lcc}
\hline \# Unemployment spells & 104,437 & 104,437 \\
\# Observations & 602,916 & 602,916 \\
$\mathrm{R}^{2}$ & 0.032 & 602,916 \\
\hline Pre-reform parallel trend (F-test, p-value) & 0.74 & \\
Post-reform parallel trend (F-test, p-value) & 0.59 &
\end{tabular}

No effect on the short-term unemployed ( $p$-value) 0.84

Note: The regressions include the same (control) variables as the benchmark specification (Table A.3). For the sake of conciseness, only the variables relevant for the placebo-tests are shown. The post-reform placebo-test does not reject the equality of the coefficients printed in bold, indicating that the parallel trend holds after the reform. The placebo-test examining the effect of the abolition of the short-term unemployed rejects that the job finding rate of jobseekers unemployed for less than five months was affected by the reform. We also test whether the parallel trend holds in the pre-reform period. This trend holds which indicates that the effectiveness of the hiring subsidy does not vary over the business cycle. Huber-White standard errors robust for heteroskedasticity in parentheses. $* * *, * *$, denote statistical significance at the $1 \%, 5 \%$ and $10 \%$ level, respectively. 
Table A.5: The effect of the abolition of the hiring subsidy on finding a job and remaining employed for 1 to 12 consecutive months (Figure 4, left panel in the main text plots the results)

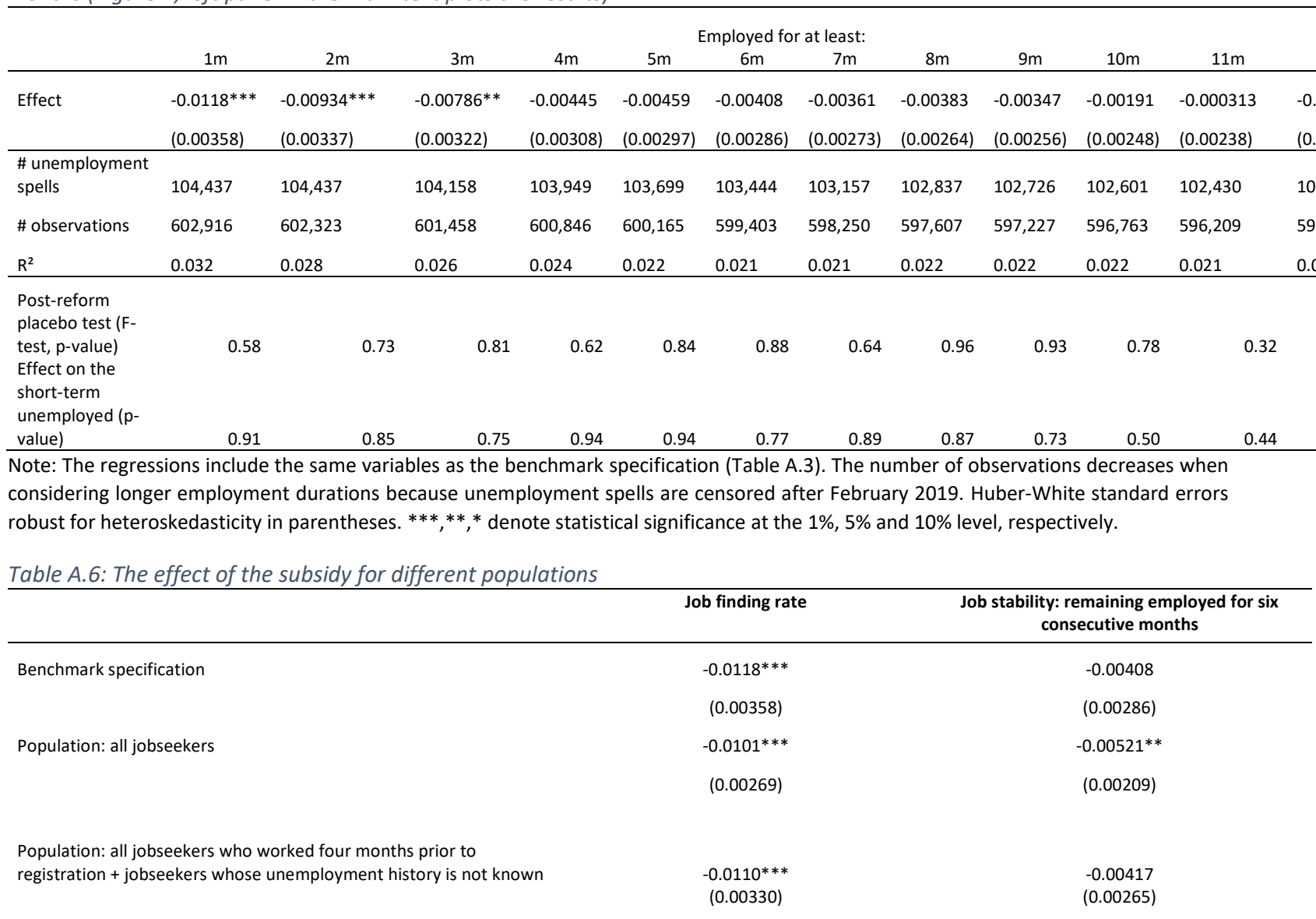

Note: The regressions include the same variables as the benchmark specification (Table A.3). In the benchmark specification, the population consists of jobseekers who have worked four consecutive months prior to becoming unemployed. The population in the second regression (row 2) includes all jobseekers regardless of the number of months worker prior to becoming unemployed. The population in the third regressions (row 3 ) excludes jobseekers who did not work four consecutive months prior to becoming unemployed, but includes jobseekers whose labour market history is not known. Huber-White standard errors robust for heteroskedasticity in parentheses. ${ }^{* * *}{ }^{* *},{ }^{*}$ denote statistical significance at the $1 \%, 5 \%$ and $10 \%$ level, respectively. 
Table A.7: The effect of the subsidy on the job finding rate, robustness checks

\begin{tabular}{|c|c|c|c|}
\hline & $\begin{array}{c}\text { Censor spells when jobseekers leave the } \\
\text { labour market }\end{array}$ & Treatment group includes jobseekers aged 44.5-48 & Effect by month \\
\hline \multirow[t]{2}{*}{ Effect } & $-0.0125 * * *$ & $-0.0113 * * *$ & \\
\hline & $(0.00394)$ & $(0.00347)$ & \\
\hline \multicolumn{4}{|l|}{ Age 45-48y \#\# post-reform } \\
\hline \multirow[t]{2}{*}{ \#\# Unemployed for 6 months } & & & $-0.0168 * *$ \\
\hline & & & $(0.00664)$ \\
\hline \multirow[t]{2}{*}{ \#\# Unemployed for 7 months } & & & -0.00731 \\
\hline & & & $(0.00678)$ \\
\hline \multirow[t]{2}{*}{ \#\# Unemployed for 8 months } & & & -0.00979 \\
\hline & & & $(0.00684)$ \\
\hline \multirow[t]{3}{*}{ \#\# Unemployed for 9-12 month } & & & \\
\hline & & & $-0.0262^{* * *}$ \\
\hline & & & $(0.00292)$ \\
\hline \# unemployment spells & 104,437 & 110,930 & 104,437 \\
\hline \# observations & 545,580 & 640138 & 602,916 \\
\hline $\mathrm{R}^{2}$ & 0.028 & 0.032 & 0.032 \\
\hline
\end{tabular}

Note: The regressions include the same variables as the benchmark specification (Table A.3). In the first regressions, unemployment spells are censored when jobseekers leave the labour market. In the second regression, jobseekers aged 44.5 to 45 at time of registration at the PES are included in the treatment group. The third regressions examines if the effect of the abolition of the subsidy depends on the unemployment duration. Huber-White standard errors robust for heteroskedasticity in parentheses. $* * * * *, *$ denote statistical significance at the $1 \%, 5 \%$ and $10 \%$ level, respectively.

Table A.8: The Breusch-Godfrey LM test on grouped errors

\begin{tabular}{lc} 
& Weighted OLS \\
\hline Lagged grouped error & $0.0526^{* * *}$ \\
& $(0.0109)$ \\
\hline $\mathrm{N}$ & 9,742 \\
$\mathrm{R}^{2}$ & 0.021 \\
\hline
\end{tabular}

Note: This table reports the results of the Breusch-Godfrey LM test of autocorrelation of the grouped error terms. We first obtain the individual error terms after estimating equation 1 (Table A.3), and compute the average error by group. A group is defined by the combination of the explanatory variables included in the regression: unemployment duration (dummies), year of registration at the PES, level of education (low, medium, high), self-reported proficiency in Dutch (3 levels), country of origin (3 levels) and sex. The grouped error term is then regressed on the lagged error grouped error term and the explanatory variables. Observations are weighted by the inverse of the variance of the dependent variables, which equals the number of observation in a group divided by $\hat{y}_{m k}\left(1-\hat{y}_{m k}\right)$ with $\hat{y}_{m k}$ the predicted probability of resuming work in group $k$ in month $m$. 
Figure A.1: The job finding rate of jobseekers aged 40 to 43 in function of elapsed unemployment duration, before and after the reform

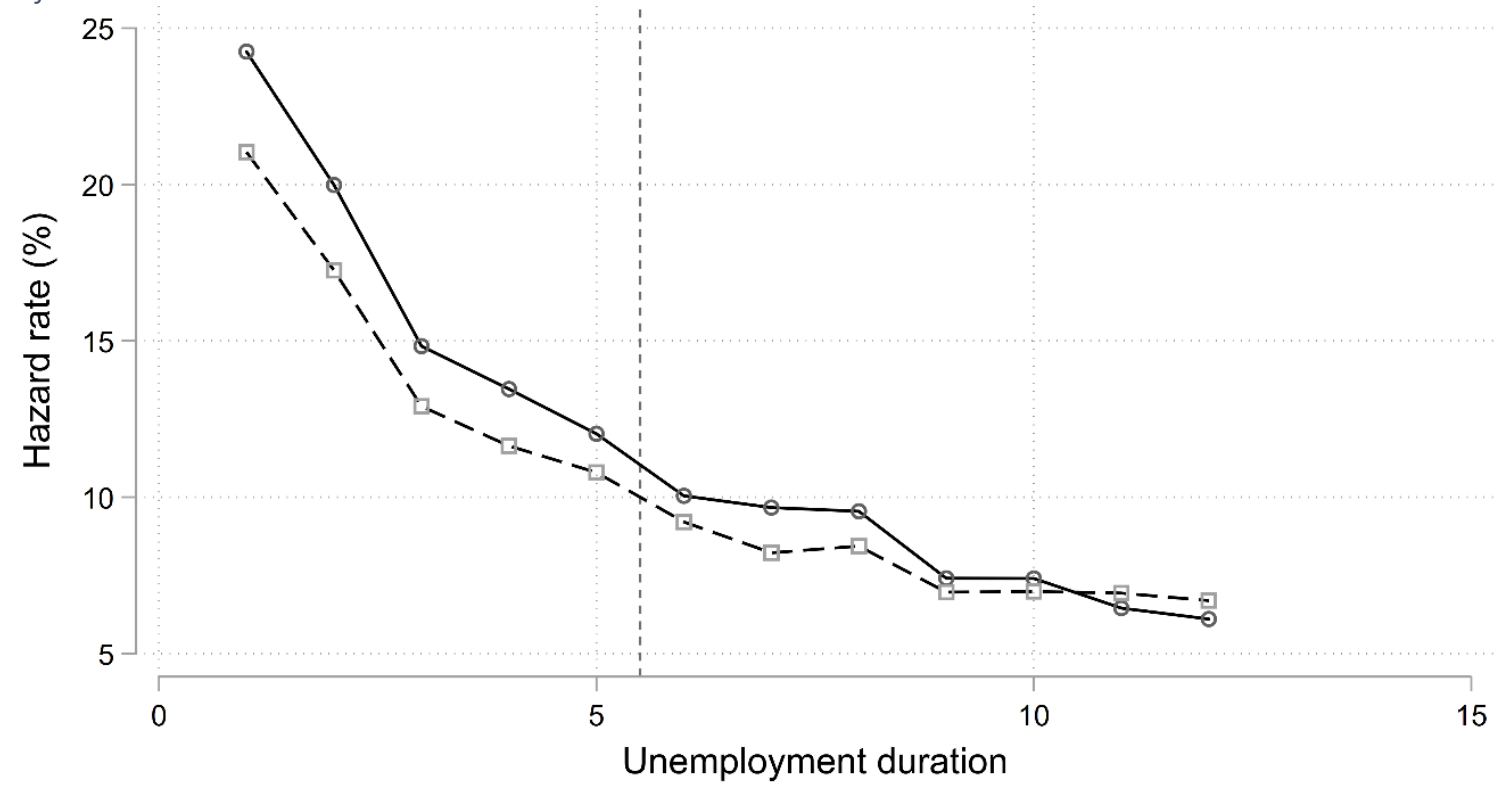

$\rightarrow-$ After the reform (jobseekers registered in 2017)

$-\square-$ Before the reform (jobseekers registered in 2015)

Note: The vertical dashed line indicates the month jobseekers aged 45 to 48 become eligible for the hiring subsidy prior to the reform.

Figure A.2: The effect of the abolition of the subsidy on the probability of finding employment lasting 1 to 12 (consecutive) months using the more stringent definition of employment
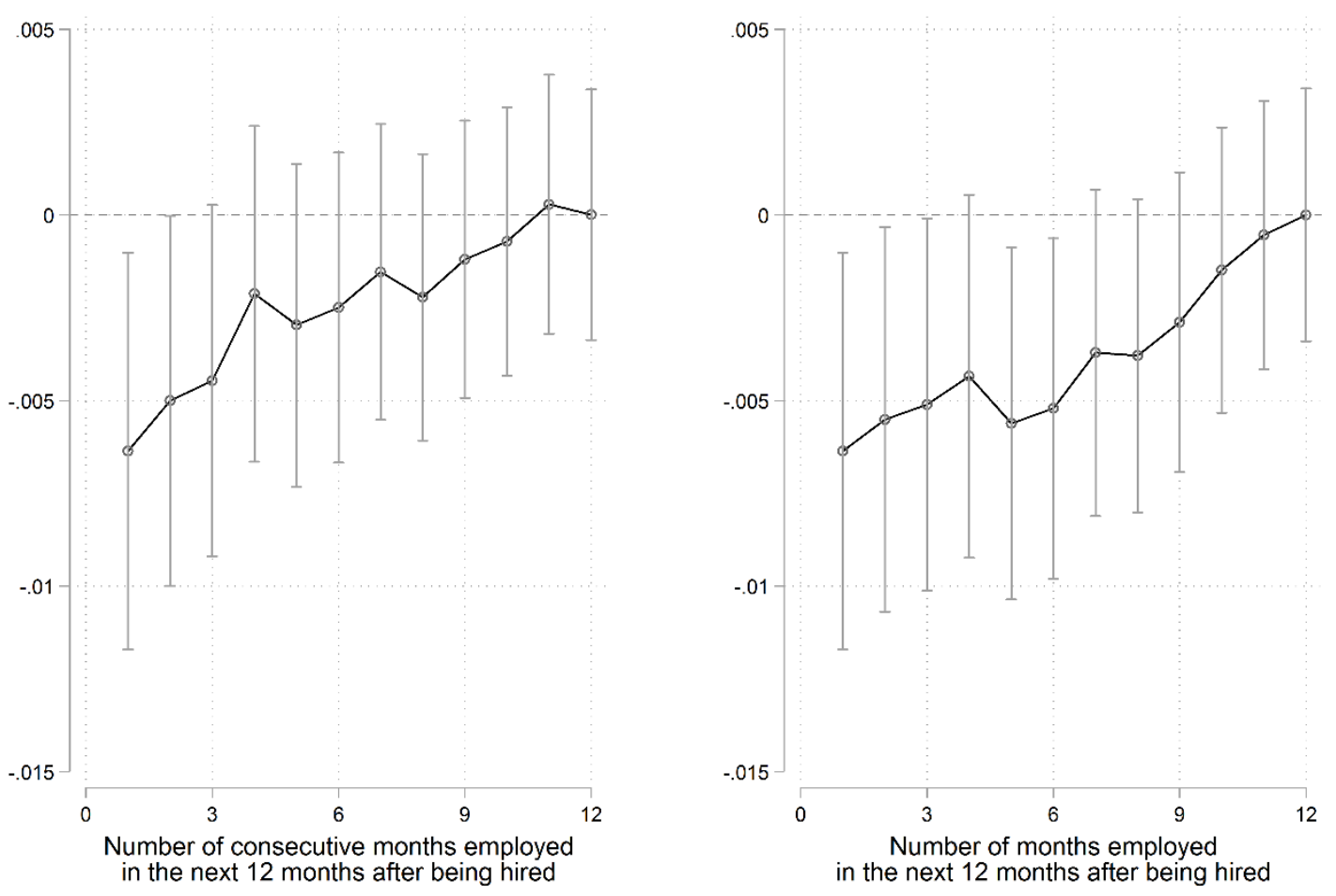

Note: Each graph shows the triple interaction term with its $95 \% \mathrm{Cl}$ obtained by estimating twelve triple difference regressions following the benchmark specification as in Table 2. The outcome is an indicator taking the value 1 if the jobseeker found a job and remained employed for 1 to 12 (consecutive) months, and zero otherwise. The definition of employment follows a more stringent definition of work, thereby excluding temporary work lasting between 10 and 20 days per month. 
Figure A.3: The evolution of long-term unemployment in Flanders among jobseekers aged 40 to 48

Number of jobseekers

by unemployment duration

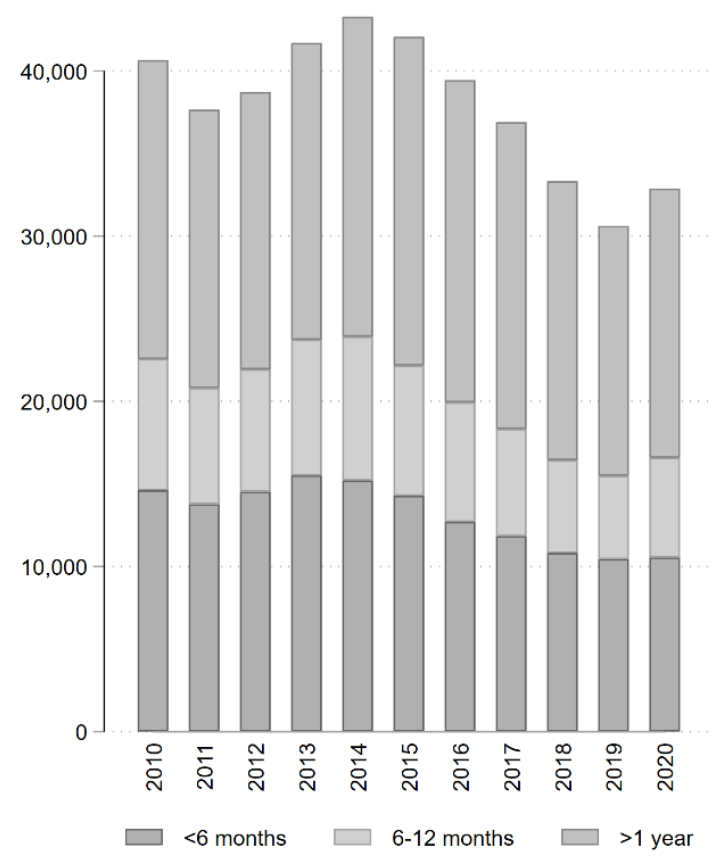

Share of jobseekers

by unemployment duration (\%)

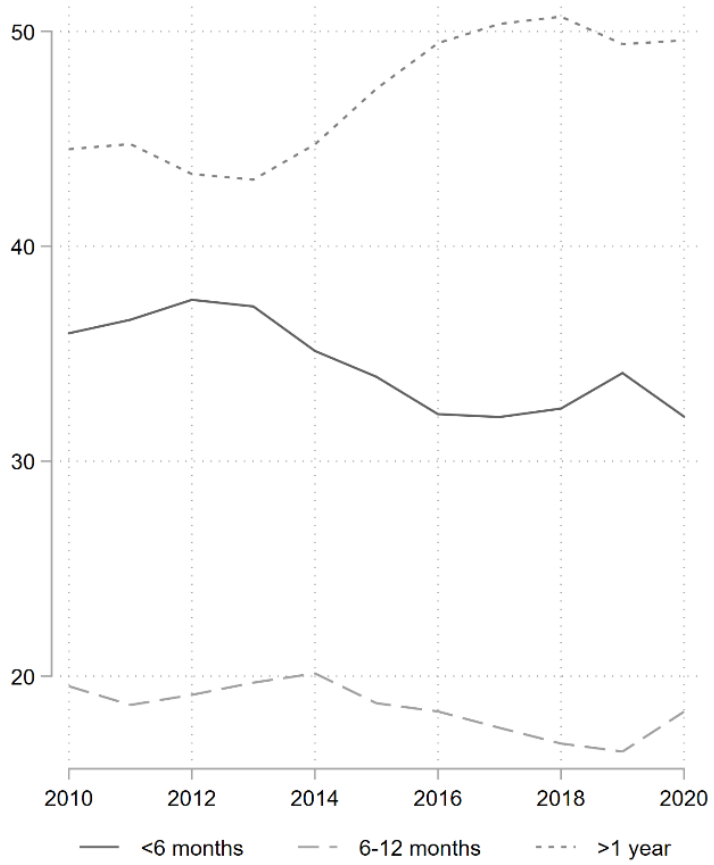

Source: Monthly average from Arvastat (https://arvastat.vdab.be/, accessed April 2021). 


\section{Appendix B: Placebo-tests for difference-in-differences specifications}

This section presents placebo-tests showing that difference-in-differences (DiD) approaches are not valid. Two distinct DiD models can be estimated. The first DiD exploits that subsidy eligibility depends on the unemployment duration. It compares the job finding rate of short-term to long-term unemployed jobseekers aged 45 to 48 (see also Figure 3 in the main text). The second DiD exploits that only older jobseekers are eligible for the subsidy, and compares the job finding rate of long-term unemployed jobseekers aged 40 to 43 to the job finding rate of long-term unemployed jobseekers aged 45 to 48 .

We start by exploiting differences across unemployment duration among older jobseekers. This approach shows that the job finding rate of the long-term unemployed aged 45 to 48 decreased by 3.52 percentage points after the abolition of the subsidy relative to the short-term unemployed in the same age group (Table B.1, regression 1). However, two placebo-tests are rejected, thereby rejecting the validity of this DiD model.

Table B.1: DiD exploiting differences across unemployment duration among older jobseekers \& placebo-tests

\begin{tabular}{|c|c|c|c|}
\hline & $\begin{array}{l}\text { DiD: Short-term vs long- } \\
\text { term unemployed, among } \\
\text { jobseekers aged } 45 \text { to } 48\end{array}$ & $\begin{array}{c}\text { Placebo-test 1: post-reform } \\
\text { parallel trends }\end{array}$ & $\begin{array}{c}\text { Placebo-test 2: jobseekers } \\
\text { aged } 40 \text { to } 43\end{array}$ \\
\hline $\begin{array}{l}\text { Post-reform \#\# long-term } \\
\text { unemployed }\end{array}$ & $\frac{-0.0352^{* * *}}{(0.00264)}$ & & $\frac{-0.0230^{* * *}}{(0.00248)}$ \\
\hline \multicolumn{4}{|l|}{$\begin{array}{l}\text { Long-term unemployed \#\# } \\
\text { year (base level: 2015) }\end{array}$} \\
\hline \multirow[t]{2}{*}{2012} & & 0.00626 & \\
\hline & & $(0.00444)$ & \\
\hline \multirow[t]{2}{*}{2013} & & $0.0162^{* * *}$ & \\
\hline & & $(0.00384)$ & \\
\hline \multirow[t]{2}{*}{2014} & & 0.00572 & \\
\hline & & $(0.00403)$ & \\
\hline \multirow[t]{2}{*}{2016 Q1-Q2 } & & -0.000136 & \\
\hline & & $(0.00548)$ & \\
\hline \multirow[t]{2}{*}{2016 Q3-Q4 } & & $-0.0194 * * *$ & \\
\hline & & $(0.00523)$ & \\
\hline \multirow[t]{2}{*}{2017} & & $-0.0283 * * *$ & \\
\hline & & $(0.00448)$ & \\
\hline \multirow[t]{2}{*}{2018} & & $-0.0377 * * *$ & \\
\hline & & $(0.00522)$ & \\
\hline \# observations & 283,469 & 283,469 & 319,447 \\
\hline$R^{2}$ & 0.034 & 0.034 & 0.031 \\
\hline $\begin{array}{l}\text { Post-reform parallel trend } \\
\text { (F-test, } p \text {-value) }\end{array}$ & & $\underline{0.012^{* *}}$ & \\
\hline
\end{tabular}

Note: The first DiD regression compares the job finding rate between the short-term and the long-term unemployed among jobseekers aged 45 to 48 , before and after the reform. The second DiD regression tests whether the job finding rate of short-term and long-term unemployed older jobseekers evolved similarly before and after the reform. The third DiD regression compares the job finding rate between the shortterm and the long-term unemployed among jobseekers aged 40 to 43 , before and after the reform. All regressions include the unemployment duration (dummies), year of registration at the PES, educational level, proficiency in Dutch, origin, sex and age. Huber-White standard errors robust for heteroskedasticity in parentheses. ${ }^{* * *},{ }^{* *},{ }^{*}$ denote statistical significance at the $1 \%, 5 \%$ and $10 \%$ level, respectively. The post-reform parallel trend test, shown at the bottom of column 2, tests whether the post-reform interaction terms (printed in bald) are jointly equal, thereby testing the parallel trend in the post-reform period.

The first placebo-test examines the parallel trend assumption (Table B.1, regression 2). In the absence of the treatment, the job finding rate of the short-term and long-term unemployed should have evolved similarly. This parallel trend assumption is rejected because the interaction terms between unemployment duration and the year of registration at the PES after the reform (i.e. when the subsidy was abolished, printed in bald) are not equal, implying that the job finding rate evolved differently after the reform for the short-term vs. long-term unemployed. 
Table B.2: DiD exploiting differences across age groups for the long-term unemployed \& placebo-tests

\begin{tabular}{|c|c|c|c|}
\hline & $\begin{array}{l}\text { DiD: Young vs older long-term } \\
\text { unemployed jobseekers }\end{array}$ & $\begin{array}{l}\text { Placebo-test 1: post-reform } \\
\text { parallel trends }\end{array}$ & $\begin{array}{l}\text { Placebo-test 2: short- } \\
\text { term unemployed }\end{array}$ \\
\hline \multirow[t]{2}{*}{ Post-reform \#\# age 45-48y } & $\underline{-0.00138}$ & & $\underline{0.0101 * * *}$ \\
\hline & $(0.00245)$ & & $(0.00261)$ \\
\hline \multicolumn{4}{|l|}{ Age 45-48y \#\# year (base level: 2015) } \\
\hline \multirow[t]{2}{*}{2012} & & $0.00769 *$ & \\
\hline & & $(0.00394)$ & \\
\hline \multirow[t]{2}{*}{2013} & & 0.00220 & \\
\hline & & $(0.00346)$ & \\
\hline \multirow[t]{2}{*}{2014} & & 0.00463 & \\
\hline & & $(0.00363)$ & \\
\hline \multirow[t]{2}{*}{2016 Q1-Q2 } & & 0.00444 & \\
\hline & & $(0.00495)$ & \\
\hline \multirow[t]{2}{*}{2016 Q3-Q4 } & & 0.00652 & \\
\hline & & $(0.00473)$ & \\
\hline \multirow[t]{2}{*}{2017} & & 0.00102 & \\
\hline & & $(0.00407)$ & \\
\hline \multirow[t]{2}{*}{2018} & & -0.00195 & \\
\hline & & $(0.00538)$ & \\
\hline \# observations & 241,611 & 241,611 & 361,305 \\
\hline $\mathrm{R}^{2}$ & 0.005 & 0.005 & 0.020 \\
\hline \multicolumn{2}{|l|}{ Post-reform parallel trend (F-test, $p$-value) } & $\underline{0.34}$ & \\
\hline \multicolumn{4}{|c|}{$\begin{array}{l}\text { Note: The first DiD regression compares the job finding rate of long-term unemployed jobseekers between younger ( } 40-43 \text { years old) and } \\
\text { older ( } 45-48 \text { years old) jobseekers, before and after the reform. The second DiD regression tests whether the job finding rate of the long- } \\
\text { term unemployed in both age groups evolved similarly after the reform (i.e. F-test testing whether the coefficients printed in bald are equal). } \\
\text { The third DiD regressions compares the job finding rate of short-term unemployed jobseekers in both age groups, before and after the } \\
\text { reform. All regressions include the unemployment duration (dummies), year of registration at the PES, educational level, proficiency in } \\
\text { Dutch, origin, sex and age. Huber-White standard errors robust for heteroskedasticity in parentheses. }{ }^{* * *}, * *, * \text { denote statistical significance } \\
\text { at the } 1 \%, 5 \% \text { and } 10 \% \text { level, respectively. The post-reform parallel trend test, shown at the bottom of column } 2 \text {, tests whether the post- } \\
\text { reform interaction terms (printed in bald) are jointly equal, thereby testing the parallel trend in the post-reform period. }\end{array}$} \\
\hline
\end{tabular}

The second placebo-test examines the job finding rate of younger jobseekers, a group that is not affected by the reform (Table B.1, regression 3). It shows that the job finding rate of long-term unemployed jobseekers aged 40 to 43 decreased by 2.30 percentage points after the reform relative to the job finding rate of the short-term unemployed in the same age group. This casts further doubt on the validity of the DiD approach. As we discuss in the main text, the job prospects of the long-term unemployed, regardless of the age group, deteriorated after the reform. It is well-known that the job prospects of the long-term unemployed are less sensitive to the economic cycle than those of the short-term unemployed (Machin and Manning 1999). These business cycle effects are not captured by the DiD approach.

The second DiD compares the job finding rate across age groups among long-term unemployed jobseekers. The DiD estimates indicate that the job finding rate of the long-term unemployed aged 45 to 48 decreased by 0.14 percentage points after the abolition of the subsidy relative to the job finding rate of the long-term unemployed aged 40 to 43 (Table B.2, col 1). The first placebo-test examines the parallel trend assumption, which is not rejected (Table B.2, regression 2). The job finding rate of longterm unemployed jobseekers aged 40 to 43 trended similarly as the job finding rate of long-term unemployed jobseekers aged 45 to 48 after the reform. The second placebo-test compares the job finding rate of short-term unemployed jobseekers across age groups (Table B.2, regression 3). The short-term unemployed should not be affected by the policy. We observe, however, that the job finding rate of the short-term unemployed aged 45 to 48 increased by 1.01 percentage points after 
the reform, relative to the job finding rate of the short-term unemployed aged 40 to 43 , suggesting that the job prospects of all older jobseekers improved after the abolition of the subsidy. This placebotest is therefore rejected. 


\section{Appendix C: Review of Card et al. (2018)}

Table C.1: Studies on the effectiveness of private employment programs for the long-term unemployed included in Card et al. (2018) (studies not included in the bibliography)

\begin{tabular}{|c|c|c|c|c|}
\hline Title & Authors & $\begin{array}{l}\text { Year of } \\
\text { publication }\end{array}$ & Journal & Country \\
\hline $\begin{array}{l}\text { Active labour market policies in Denmark: A comparative } \\
\text { analysis of post-program effects }\end{array}$ & Blanche, G. & 2011 & $U$ & Denmark \\
\hline $\begin{array}{l}\text { Evaluating the impact of a well targeted wage subsidy using } \\
\text { administrative data. }\end{array}$ & $\begin{array}{l}\text { Cseres-Gergely, Z., Scharle, Á., } \\
\text { Földessy, Á. }\end{array}$ & 2012 & $\mathrm{U}$ & Hungary \\
\hline $\begin{array}{l}\text { The effectiveness of targeted wage subsidies for hard-to-place } \\
\text { workers }\end{array}$ & Jaenichen, U., Stephan G. & 2011 & $\begin{array}{l}\text { Applied } \\
\text { Economics }\end{array}$ & Germany \\
\hline $\begin{array}{l}\text { Evaluation of Subsidized Employment Programs for Long-Term } \\
\text { Unemployed in Bulgaria }\end{array}$ & Mihaylov, E. & 2011 & $\begin{array}{l}\text { Economic } \\
\text { Studies }\end{array}$ & Bulgaria \\
\hline $\begin{array}{l}\text { Do long-term unemployed workers benefit from targeted wage } \\
\text { subsidies? }\end{array}$ & $\begin{array}{l}\text { Schünemann, B., Lechner, M., Wunsch, } \\
\text { C. }\end{array}$ & 2013 & $\begin{array}{l}\text { German } \\
\text { Econ Rev }\end{array}$ & Germany \\
\hline $\begin{array}{l}\text { Employment subsidies: A fast lane from unemployment to } \\
\text { work? }\end{array}$ & $\begin{array}{l}\text { Forslund, A., Johansson, P., Lindquist, } \\
\text { L. }\end{array}$ & 2004 & $\mathrm{U}$ & Sweden \\
\hline $\begin{array}{l}\text { Income Support Policies for Part-Time Workers: A Stepping- } \\
\text { Stone to Regular Jobs? An Application to Young Long-Term } \\
\text { Unemployed Women in Belgium. }\end{array}$ & Cockx, B., Robin, S., Goebel, C. & 2010 & $u$ & Belgium \\
\hline $\begin{array}{l}\text { Dynamic Treatment Assignment: The Consequences for } \\
\text { Evaluations using Observational Data. }\end{array}$ & Fredriksson, P., Johansson, P. & 2008 & 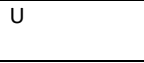 & Sweden \\
\hline $\begin{array}{l}\text { Do active labor market policies help unemployed workers to } \\
\text { find and keep regular jobs? }\end{array}$ & Van Ours, J. & 2000 & Book & Slovakia \\
\hline The locking-in effect of subsidized jobs. & Van Ours, J. & 2004 & $\begin{array}{l}\text { Journal of } \\
\text { Comparative } \\
\text { Economics }\end{array}$ & Slovakia \\
\hline
\end{tabular}

Note: U refers "Unpublished". 